\title{
Site U1375
}

\author{
Expedition 330 Scientists $^{2}$
}

\section{Chapter contents}

Background and objectives.......... 1

Operations....................

Sedimentology ..................

Paleontology ...................

Igneous petrology and volcanology ......6 6

Alteration petrology $\ldots \ldots \ldots \ldots \ldots \ldots \ldots$

Structural geology. . . . . . . . . . 8

Geochemistry ................. 8

Physical properties ..............9

Paleomagnetism ................ 10

References....................... 11

Figures................... 13

Tables..................... 26

${ }^{1}$ Expedition 330 Scientists, 2012. Site U1375. In Koppers, A.A.P., Yamazaki, T., Geldmacher, J., and the Expedition 330 Scientists, Proc. IODP, 330: Tokyo (Integrated Ocean Drilling Program Management International, Inc.). doi:10.2204/iodp.proc.330.106.2012

'Expedition 330 Scientists' addresses.

\section{Background and objectives}

Site U1375 (prospectus Site LOUI-2B) on Achernar Guyot was the fourth site completed during Integrated Ocean Drilling Program (IODP) Expedition 330. Achernar Guyot (Fig. F1), the third of five seamounts drilled in the Louisville Seamount Trail, has an estimated age of $\sim 59-63 \mathrm{Ma}$. Knowledge of this feature will fill an important gap in the age-versus-distance relationship of the Louisville Seamount Trail and will also provide information pivotal to reconstructing past plate motion and the motion of the Louisville hotspot. Compared to Rigil and Canopus Guyots to the northwest, this seamount is half the size (29 km long and $27 \mathrm{~km}$ wide) and is part of a trail of seven small guyots and seamounts that starts with Burton Guyot at the northern end (Fig. F1). Site U1375 was targeted in the middle of this small edifice (Fig. F2), away from the guyot's shelf edges and any thick packages of dipping volcaniclastics on its flanks, the latter of which were preferentially targeted at Sites U1372, U1373, and U1374. Achernar Guyot shows no evidence of tilting, and Site U1375 was placed on its summit plain at $1258 \mathrm{~m}$ water depth. Side-scan sonar reflectivity and $3.5 \mathrm{kHz}$ subbottom profiling data indicate that Site U1375 is covered with $<15 \mathrm{~m}$ of pelagic sediment, and seismic reflection profiles suggest that this central part of Achernar Guyot is typified by $<44 \mathrm{~m}$ of volcaniclastics overlying igneous basement.

The original drilling plan was to recover soft sediment using a gravity-push approach with little or no rotation of the rotary core barrel assembly, followed by standard coring into the volcaniclastic materials and $350 \mathrm{~m}$ into igneous basement. A short downhole logging series was planned, including the standard triple combination and Formation MicroScanner-sonic tool strings and the third-party Göttingen Borehole Magnetometer tool. Shortly after Hole U1375A was spudded, drilling became problematic because of instabilities in the uppermost seamount sediment cover, likely from the presence of unconsolidated cobbles. After Hole U1375A had to be abandoned, Hole U1375B was spudded $\sim 350 \mathrm{~m}$ to the northwest, but severe hole instabilities were also encountered there. In order to avoid further delay at yet another location on Achernar Guyot, Hole U1375B was abandoned and a new site was established on Burton Guyot about $91 \mathrm{nmi}$ to the northwest along the Louisville Seamount Trail. Despite the drilling difficulties, three cores were recovered, including $\sim 1.5 \mathrm{~m}$ of carbonate- 
cemented volcanic breccia in Hole U1375A and $57 \mathrm{~cm}$ of micrograbbro (dolerite) in Hole U1375B.

\section{Objectives}

Drilling during Ocean Drilling Program (ODP) Leg 197 provided compelling evidence for the motion of mantle plumes by documenting a large $\sim 15^{\circ}$ shift in paleolatitude for the Hawaiian hotspot (Tarduno et al., 2003; Duncan et al., 2006). This evidence led to testing two geodynamic end-member models during Expedition 330, namely that the Louisville and Hawaiian hotspots moved coherently over geological time (Wessel and Kroenke, 1997; Courtillot et al., 2003) or, quite the opposite, that these hotspots show considerable interhotspot motion, as predicted by mantle flow models (Steinberger, 2002; Steinberger et al., 2004; Koppers et al., 2004; Steinberger and Antretter, 2006; Steinberger and Calderwood, 2006). The most important objective of Expedition 330 , therefore, was to core deep into the igneous basement of four seamounts in the Louisville Seamount Trail in order to sample a large number of in situ lava flows ranging in age between 80 and $50 \mathrm{Ma}$. With a sufficiently large number of these independent cooling units, high-quality estimates of their paleolatitude can be determined, and any recorded paleolatitude shift (or lack thereof) can be compared with seamounts in the Hawaiian-Emperor Seamount Trail. For this reason, Expedition 330 mimicked the drilling strategy of Leg 197 by drilling seamounts equivalent in age to Detroit (76-81 Ma), Suiko (61 Ma), Nintoku (56 Ma), and Koko (49 Ma) Seamounts in the Emperor Seamount Trail, with Achernar Guyot being equivalent to Suiko Seamount. Accurate paleomagnetic inclination data are required for the drilled seamounts in order to establish a record of past Louisville hotspot motion, and, together with high-resolution ${ }^{40} \mathrm{Ar} /{ }^{39} \mathrm{Ar}$ age dating of the cored lava flows, these data will help us constrain the paleolatitudes of the Louisville hotspot between 80 and $50 \mathrm{Ma}$. These comparisons are of fundamental importance in determining whether these two primary hotspots have moved coherently or not and in understanding the nature of hotspots and convection in the Earth's mantle.

Expedition 330 also aimed to provide important insights into the magmatic evolution and melting processes that produced and constructed Louisville volcanoes as they progressed from shield to postshield, and perhaps posterosional, volcanic stages. Existing data from dredged lava suggest that the mantle source of the Louisville hotspot has been remarkably homogeneous for as long as 80 m.y. (Cheng et al., 1987; Hawkins et al., 1987; Vanderkluysen et al., 2007; Beier et al., 2011). In addition, all dredged ba- salt is predominantly alkalic and possibly represents a mostly alkalic shield-building stage, in contrast to the tholeiitic shield-building stage of volcanoes in the Hawaiian-Emperor Seamount Trail (Hawkins et al., 1987; Vanderkluysen et al., 2007; Beier et al., 2011). Therefore, the successions of lava flows cored during Expedition 330 will help us characterize the Louisville Seamount Trail as the product of a primary hotspot and test the long-lived homogeneous geochemical character of its mantle source. Analyses of melt inclusions, volcanic glass samples, high-Mg olivine, and clinopyroxene phenocrysts will provide further constraints on the asserted homogeneity of the Louisville plume source, its compositional evolution between 80 and $50 \mathrm{Ma}$, its potential mantle plume temperatures, and its magma genesis, volatile outgassing, and differentiation. Incremental heating ${ }^{40} \mathrm{Ar} /{ }^{39} \mathrm{Ar}$ age dating will allow us to establish age histories within each drill core, delineating any transitions from the shield-building phase to the postshield capping and posterosional stages.

Finally, basalt and sediment cored at Site U1375 were planned to be used for a range of secondary objectives such as searching for active microbial life in the old seamount basement and determining whether fossil traces of these microbes were left behind in volcanic glass or rock biofilms. We also planned to determine ${ }^{3} \mathrm{He} /{ }^{4} \mathrm{He}$ and ${ }^{186} \mathrm{Os} /{ }^{187} \mathrm{Os}$ signatures of the Louisville mantle plume to evaluate its potential deep-mantle origin, to use oxygen and strontium isotope measurements on carbonates and zeolites in order to assess the magnitude of carbonate vein formation in aging seamounts and its role as a global $\mathrm{CO}_{2}$ sink, to age date celadonite alteration minerals for estimating the total duration of low-temperature alteration following seamount emplacement, and to determine the hydrogeological and seismological character of the seamount basement.

\section{Operations}

The $322 \mathrm{nmi}$ voyage to Site U1375 on Achernar Guyot was accomplished at an average speed of 10.2 kt. During the transit the vessel pitched and rolled moderately in rough sea conditions, and waves occasionally broke across the deck. As the transit progressed, improving weather and course adjustments made the transit more comfortable. The vessel was on station above Hole U1375A at $0330 \mathrm{~h}$ on 25 January 2011 (all times are New Zealand Daylight Time, Universal Time Coordinated [UTC] + $13 \mathrm{~h}$ ).

In accordance with the established routine of the expedition, the vibration-isolated television frame was deployed prior to spudding the hole. The bit tagged the seafloor at 1269.0 meters below rig floor (mbrf; 
1258 meters below sea level [mbsl]), $0.9 \mathrm{~m}$ shallower than the corrected precision depth recorder depth. Hole U1375A was spudded with the rotary core barrel assembly outfitted with a Type C- 4 bit at $1345 \mathrm{~h}$ on 25 January (Table T1). Almost immediately, the driller experienced erratic high torque, indicating that we were attempting to core through loose rocks and boulders. Frequent overpulls of up to 90,000 lb were required to keep the drill string rotating freely. At $2130 \mathrm{~h}$, coring of Hole U1375A was terminated at 11.5 meters below seafloor (mbsf) because of unstable hole conditions. The average recovery for just two cores was $13 \%$.

The vessel was offset $300 \mathrm{~m}$ at $315^{\circ}$, and a second attempt at coring this site was initiated when Hole U1375B was spudded at $2345 \mathrm{~h}$. The water depth was again 1269.0 mbrf, corresponding to $1258 \mathrm{mbsl}$. After penetrating $8.5 \mathrm{~m}$ with increasing difficulty and constantly fighting unstable hole conditions, operations in this hole were terminated as well. The lone core retrieved had an average recovery of $7 \%$. It was concluded that the formation on the top of this seamount consisted of sedimentary breccia loosely held together in a "soft" carbonate matrix that quickly disintegrated during drilling, leaving mainly loose pebbles behind. The vessel departed at $1945 \mathrm{~h}$ on 26 January for an approved alternate site (LOUI-7A), located $91 \mathrm{nmi}$ north-northwest of Site U1375 on Burton Guyot. The total time spent at Site U1375 was $34.3 \mathrm{~h}$ (1.4 days).

\section{Sedimentology}

Sediment recovered from Hole U1375A, which penetrated to only $10.11 \mathrm{mbsf}$, represents a younger pelagic cap and older sedimentary cover of Achernar Guyot. No significant amount of sediment was recovered from Hole U1375B, except for a very small amount of foraminiferal debris recovered from the core catcher of Core 330-U1375B-1R (see "Paleontology"). Two stratigraphic units were defined in Hole U1375A on the basis of the compositional and textural characteristics of the sediment at macroscopic and microscopic scales (Fig. F3):

- Unit I (0-0.02 mbsf; lower boundary = Section 330-U1375A-1R-CC, $2 \mathrm{~cm}$ ): pelagic cap of the drilled seamount. Cuttings from the core catcher suggest it is predominantly composed of pale yellow sandy foraminiferal ooze.

- Unit II (8.50-10.11 mbsf; lower boundary = Section 330-U1375A-2R-2, $13 \mathrm{~cm}$ ): older sedimentary cover of seamount. This unit is composed of multicolor basalt conglomerate with ferromanganese encrustations and multicolor basalt breccia. Unit II was divided into two subunits (see below).

\section{Unit I}

Interval (sampled): Sections 330-U1375A-1R-CC, $0 \mathrm{~cm}$, to $1 \mathrm{R}-\mathrm{CC}, 2 \mathrm{~cm}$

Depth (interpreted): 0-8.50 mbsf

Age: late Miocene to Holocene

Sedimentary observation for the uppermost part of Achernar Guyot (8.50 mbsf and above) was limited to a few cuttings that accumulated in the core catcher during retrieval of Core 330-U1375A-1R. The composition and age of the cuttings (see "Paleontology") suggest that the sediment is similar to that forming the young unconsolidated pelagic caps observed at Sites U1372 and U1374 on Canopus and Rigil Guyots, respectively. Therefore, stratigraphic Unit I at Site U1375 is taken to represent the youngest sedimentary cover or pelagic cap. Its lower boundary at $\sim 8.50 \mathrm{mbsf}$ is inferred to correspond to a $2 \mathrm{~cm}$ thick ferromanganese encrustation on top of underlying Unit II (see below), which we interpret to represent the first occurrence downhole of a consolidated deposit (Fig. F3). The sediment of Unit I is composed of pale yellow unconsolidated sandy foraminiferal ooze with glass fragments. Its age is constrained by foraminiferal and nannofossil assemblages from the late Miocene to Holocene (see "Paleontology"). Smear slide observations (Sample 330-U1375A-1R-CC-PAL-SED, 0-2 cm) showed that the sandy foraminiferal ooze includes some fragments of fresh volcanic glass and pyroxene.

\section{Unit II}

Interval: Sections 330-U1375A-2R-1, 0 cm, to 2R-2, $13 \mathrm{~cm}$

Depth: 8.50-10.11 mbsf

Age: Paleocene (Subunit IIA) and late Paleocene or older (Subunit IIB)

Stratigraphic Unit II represents an older, $1.61 \mathrm{~m}$ thick sedimentary cover extending from 8.50 to 10.11 mbsf. Unit II reaches to the bottom of Hole $\mathrm{U} 1375 \mathrm{~A}$, and its lower boundary could not be defined because drilling was abandoned early as a result of hole instability. Its upper boundary is defined by a $2 \mathrm{~cm}$ thick ferromanganese encrustation at 8.50 mbsf. Unit II is composed of lithified basalt conglomerate or breccia. Distinct sedimentary compositions, textures, and fossil contents allowed Unit II to be divided into two subunits (Fig. F3). The high induration and consistent sedimentary textures in Subunit IIA and the occurrence of stronger alteration and the softer character of sediment in Subunit IIB (see "Alteration petrology") suggest that the poor recovery of Core 330-U1375A-2R (49\%) is probably related to disaggregation during drilling of Subunit IIB. The basalt clast types of Unit II are provided in 
Table T2 and in U1375A.DOC in CHAR in SEDIMENT in "Supplementary material." Estimates of the size and roundness of grains with depth (see "Sedimentology" in the "Methods" chapter [Expedition 330 Scientists, 2012a]) are illustrated in Figure F3 and provided in a supplementary table (see U1375A.XLS in SIZE in SEDIMENT in "Supplementary material").

\section{Subunit IIA}

Interval: Sections 330-U1375A-2R-1, $0 \mathrm{~cm}$, to 2R-1, $84 \mathrm{~cm}$

Depth: 8.50-9.34 mbsf

Age: Paleocene

Stratigraphic Subunit IIA is $0.84 \mathrm{~m}$ thick and extends from 8.50 to $9.34 \mathrm{mbsf}$ (Fig. F3). Its lower boundary corresponds to the top of underlying multicolor basalt breccia (Subunit IIB; see below). Subunit IIA is composed of heterolithic grain-supported, poorly sorted multicolor basalt conglomerate (Fig. F4). The intercobble spaces include whitish-yellow foraminiferal limestone, sand- to granule-size volcaniclasts, calcite cement, and voids. The limestone is characterized by a complicated white-to-yellow color pattern and local occurrences of black (ferromanganese?) dentrites. The yellow limestone is characterized by higher phosphorus content than the white limestone (see XL3_EVAL.PDF in XRF in "Supplementary material"), supporting alteration of the limestone by postdepositional, probably metasomatic, processes (Murdmaa et al., 1995). The conglomerate clasts are composed of abundant basalt pebbles and cobbles (see "Igneous petrology and volcanology"), a few pebble- and cobble-bearing volcanic sandstones with bioclasts, and rare granule-size pebbles of bioclast limestone. The largest clasts per $10 \mathrm{~cm}$ interval are composed of basalt cobbles, and the average clast roundness is angular to subangular. Smaller sized grains are, however, well rounded to angular. The intercobble and interboulder spaces include current structures with a (minor) erosional contact at $\sim 9.28$ mbsf (Section 330-U1375A-2R-1, $78 \mathrm{~cm}$ ), geopetal structures formed by infilling of hemipelagic and volcaniclastic sediments, and possible sediment-flow structures. Distinct limestone poorer in foraminifers was observed in the conglomerate matrix between the erosional contact and underlying Subunit IIB (interval 330-U1375A-2R-1, 78-84 cm). Minor bioturbations were observed in the whitish-yellow foraminiferal limestone uphole (interval 330-U1375A-2R-1, $15-25 \mathrm{~cm}$ ). The age of Subunit IIA was constrained by foraminiferal and nannofossil assemblages from the early to late Paleocene (see "Paleontology").

Thin section observations (Samples 330-U1375A2R-1, 26-29 cm [Thin Section 224], and 2R-1, 67-70 $\mathrm{cm}$ [Thin Section 225]), showed that the intercobble and interboulder spaces include rare shallow-marine bioclasts (red algae, echinoderms, shell fragments, and bryozoans) and granular calcite cement. Clasts of vitric sandstone composed of altered vesicular glass fragments with altered olivine contain rare dissolved shell fragments and possible red algae. Also, these clasts contain three generations of cement (fringing fibrous zeolite, fringing fibrous calcite, and sparry calcite, in order of formation), and sedimentary textures show they were lithified before reworking.

\section{Subunit IIB}

Interval: Sections 330-U1375A-2R-1, $84 \mathrm{~cm}$, to 2R-2, $13 \mathrm{~cm}$

Depth: 9.34-10.11 mbsf

Age: late Paleocene or older

Stratigraphic Subunit IIB is $0.77 \mathrm{~m}$ thick and extends from 9.34 to 10.11 mbsf (Fig. F3). Its lower boundary was not recovered. Subunit IIA is composed of monolithic matrix-supported poorly sorted multicolor basalt breccia (Fig. F4). The matrix of the breccia is composed of cemented volcanic sandstone without bioclasts. The sediment of Subunit IIB is very altered (see "Alteration petrology"). The larger clasts range in size from granule to cobble, and average clast roundness is angular to very angular. Subunit IIB clasts differ from those of Subunit IIA and include basalt pebbles and cobbles with a jigsaw-fit texture (Fig. F4B; see also "Igneous petrology and volcanology"). Sedimentary infills and cement found along the upper edge of some of the cobbles with a jigsawfit texture suggest that the basalt clasts were reworked from an older sedimentary or volcanic deposit during or prior to formation of Subunit IIB.

Microscope observations (Sample 330-U1375A-2R-1, 137-141 cm [Thin Section 226]) indicated that the sediment is predominantly composed of altered vesicular glass fragments with rare fresh olivine.

\section{Interpretation of sediment at Site U1375}

Although sediment retrieved from the uppermost part of Hole U1375A was restricted to cuttings found in Core 330-U1375A-1R, our observations and the faunal assemblages (see "Paleontology") suggest that Unit I represents a pelagic cap similar to those found at Sites U1372 and U1374 on Canopus and Rigil Guyots, respectively. Similar to previous Expedition 330 sites, the pelagic cap at Site U1375 may represent a winnowed residue of ooze initially richer in nannofossils.

Unit II in Hole U1375A is interpreted as the uppermost part of an older sedimentary cover on Achernar 
Guyot. On the basis of a ferromanganese encrustation that occurs at the top of Unit II, the texture of the foraminiferal limestone found in the conglomerate matrix, and the absence of shallow-marine organisms apart from few reworked sediment clasts, we interpret Subunit IIA as a hemipelagic, partly metasomatized interval deposited during drowning of Achernar Guyot. Nannofossils and foraminifers indicate an early to middle Paleocene age of deposition (see "Paleontology"). The basalt breccia of Subunit IIB is interpreted as a debris flow deposit on the basis of its matrix-supported texture and lack of foraminiferal limestone.

Only a few cuttings were retrieved from the core catcher of Core 330-U1375B-1R in Hole U1375B, including abundant basalt grains, minor ferromanganese fragments, rare foraminifers, clinopyroxene grains, and limestone fragments with black dentrites. These observations point toward the existence of a similar sedimentary sequence in Holes U1375A and U1375B.

\section{Paleontology}

Rotary core barrel drilling in Hole U1375A retrieved only foraminiferal debris in the core catcher of Core $330-\mathrm{U} 1375 \mathrm{~A}-1 \mathrm{R}$, with all $8.5 \mathrm{~m}$ of sediment presumably flushed away during the drilling process. This sample contained $<25 \mathrm{~cm}^{3}$ of sandy foraminiferal ooze with a small percentage of fine fraction, including nannofossils. The sediment sample recovered from the core catcher is assumed to be a mixture of sediment grains from the entire $8.5 \mathrm{~m}$ interval drilled and was assigned a preliminary age of latest Miocene-Holocene (Fig. F5; Tables T3, T4). In addition to soft-sediment analysis, smear slides and thin sections taken from the consolidated basalt conglomerate of Subunit IIA were analyzed for microfossil biostratigraphy. On the basis of samples taken from Core 2R, a preliminary Paleocene (Danian-Thanetian) age was assigned to Subunit IIA.

Hole U1375B was drilled $300 \mathrm{~m}$ from Hole U1375A, and again only a small amount of rock cuttings $(<10$ $\mathrm{cm}^{3}$ ) and a very small amount of foraminiferal debris were recovered from the core catcher of Core 330U1375B-1R. The extremely poor preservation of microfossils prevented age determination of these rock cuttings. The majority of the core in Hole U1375B is composed of microgabbro (Unit I; see "Igneous petrology and volcanology").

\section{Calcareous nannofossils}

\section{Unit I}

In Hole U1375A on Achernar Guyot, one smear slide was prepared from the sediment of Unit I within the core catcher of Core 330-U1375A-1R. This smear slide contains a mixed assemblage of Neogene and Quaternary species. Present species include Discoaster variabilis, Helicosphaera sellii, Helicosphaera kamptneri, Ceratolithus cristatus, Umbilicosphaera sibogae, Coccolithus pelagicus, Calcidiscus leptoporus, Rhabdosphaera clavigera, Pseudoemiliania lacunosa, and small Gephyrocapsa. The preliminary age of this mixed assemblage is assigned to approximately Zones CN10CN15 (uppermost Miocene to Holocene).

\section{Unit II}

Two additional samples were taken from Sections $330-\mathrm{U} 1375 \mathrm{~A}-2 \mathrm{R}-1,13 \mathrm{~cm}$, and 2R-1, $32 \mathrm{~cm}$, from the consolidated carbonate matrix of Subunit IIA (Fig. F3). However, calcareous nannofossils were present at rare abundance levels in both samples, and relatively poor preservation made immediate recognition of individual species difficult. In Sample 2R-1, $13 \mathrm{~cm}$, specimens of Prinsius (Neobiscutum) dimorphosus were identified in association with apparent examples of other Prinsius sp. On the basis of the presence of $P$. dimorphosus a preliminary age of Zones CP1b-CP3 (range of $P$. dimorphosus) from the early Paleocene was assigned. Preservation in Sample 2R-1, $32 \mathrm{~cm}$, is quite poor, and individual species will be identified during postexpedition study. Samples of Subunit IIB were completely barren of nannofossils.

\section{Planktonic foraminifers}

\section{Unit I}

Samples 330-U1375A-1R-CC and 330-U1375B-1R-CC (Unit I) contain $<25$ and $10 \mathrm{~cm}^{3}$ of sandy foraminiferal ooze, respectively, although most of the foraminiferal tests in Sample 330-U1375B-1R-CC were broken into pieces. Therefore, only Sample 330-U1375A-1R-CC was used for planktonic foraminiferal analyses. This sample contains Globorotalia (Globoconella) inflata, Globorotalia (Truncorotalia) crassaformis, and Globorotalia (Truncorotalia) truncatulinoides (Table T4). During the washing procedure only a small amount of fine fraction was washed away, indicating that this sediment is composed mainly of foraminiferal tests $(>50 \%)$. Almost all foraminiferal specimens have whitish tests, and some are glassy. Although only a few individuals are filled with calcite cement, most show no sign of calcite overgrowth and cementation. In addition to the abundantly encountered species listed above, Globigerinoides extremus and Sphaeroidinellopsis cf. seminulina (indicating approximately earliest Pleistocene and approximately early Pliocene, respectively) were identified in this sample. Considering that no drilling mud was pumped during the drilling of Core 1R, Sample 1R-CC likely contains foraminiferal tests from all horizons of the $8.5 \mathrm{~m}$ interval drilled, explain- 
ing the co-occurrence of these heterochthonous species. On the basis of the occurrence of these planktonic foraminifers, the preliminary age assigned to this Unit I sample is late Miocene-Holocene (Fig. F5).

\section{Unit II}

In addition to this core catcher sample, thin sections taken from the consolidated conglomerate of Subunit IIA were examined. The matrix of this conglomerate is mostly composed of fossiliferous micrite. Although macrofossil bioclasts such as algae, bryozoans, and echinoderms are rare in the matrix, abundant foraminifers are preserved within thin sections. Triplicate thin sections were made from Samples 330-U1375A2R-1, 26-29 cm, and 2R-1, 67-70 cm (Table T5). Sample 2R-1, 26-29 cm (8.76 mbsf), contains Acarinina spp., Globanomalina cf. pseudomenardii, Igorina sp. (Igorina albeari?), Morozovella sp. (Morozovella angulata?), and other planktonic foraminifers with globular and serial morphologies (Fig. F6). On the basis of the occurrence of these species, this sample was correlated to planktonic foraminiferal Zones P4a-P4c (Selandian-Thanetian). Sample 2R-1, 67-70 cm (9.17 mbsf), contains only a few planktonic foraminifers. Age-diagnostic species were not identified in this sample. Subunit IIB samples were completely barren of planktonic foraminifers.

\section{Preliminary age estimation for Site U1375}

On the basis of nannofossil and planktonic foraminiferal analyses, the preliminary age of the sandy foraminiferal ooze of Unit I was assigned to the late Miocene-Holocene. Because all sediment from Unit I, with the exception of $<25 \mathrm{~cm}^{3}$ of sediment within the core catcher, was washed away during core retrieval, the stratigraphic distribution of microfossils could not be identified.

Although Sample 330-U1375A-2R-1, 13 cm (8.63 mbsf), from Subunit IIA contains Danian-Selandian ( 60-64.5 Ma) nannofossils, Sample 2R-1, 26-29 cm (8.76 mbsf), yields an asynchronous suite of Selandian-Thanetian (55.9-55.2 Ma) planktonic foraminifers. Visual observation of hand specimens and thin section analyses indicate that the Subunit IIA conglomerate contains not only basalt grains but also allochthonous micrite grains within its matrix. The heterogeneity of the micritic portion of Subunit IIA may explain the disparity in age between calcareous nannofossils and planktonic foraminifers. In addition, provincialisms of microfossils should be taken into account. Nevertheless, both nannofossils and planktonic foraminifers indicate a preliminary Paleocene age for Subunit IIA. Precise postexpedition microfossil analyses will clarify the nature of the disparity of age estimation of Subunit IIA.

At the top of the basalt conglomerate of Unit II, a ferromanganese crust forms the boundary between Units I and II, consistent with a significant time gap between these units. Microfossil age determinations for the foraminiferal ooze of Unit I and the conglomerate of Unit II indicate that a sequence of $>40$ m.y. is missing (Fig. F5).

\section{Igneous petrology and volcanology}

Two short holes were drilled on Achernar Guyot. Hole U1375A was drilled to a total depth of 11.5 mbsf and recovered $1.5 \mathrm{~m}$ of sedimentary rocks containing five types of volcanic clasts. The clast types found in Subunits IIA and IIB include aphyric basalt, moderately olivine-augite-phyric basalt, moderately augite-olivine-plagioclase-phyric basalt, and highly olivine-augite-phyric basalt. Hole U1375B was drilled to a total depth of $8.5 \mathrm{mbsf}$, recovering $57 \mathrm{~cm}$ of igneous rock. Unit I, the only unit to be defined for Hole U1375B, is moderately olivine-augitephyric microgabbro (dolerite) with olivine and augite phenocrysts smaller than $10 \mathrm{~mm}$.

\section{Hole U1375A}

\section{Basaltic clasts in sedimentary Subunits IIA and IIB}

The larger basaltic clasts within the conglomerate and breccia of stratigraphic Subunits IIA and IIB were divided into five types on the basis of their appearance in hand specimen. These clast types are described below, and the sedimentary subunit(s) in which they were found is noted (see "Sedimento$\left.\log y^{\prime \prime}\right)$ :

- Type 1 (Subunits IIA and IIB): aphyric basalt that is mottled gray-brown with no phenocrysts. The groundmass is fine grained and moderately altered, with no vesicles. Brown alteration halos are associated with carbonate-filled veins. Four Type 1 clasts were found in Subunit IIA and one was found in Subunit IIB.

- Type 2 (Subunit IIA): moderately olivine-augitephyric basalt that is medium gray-orange, with $5 \%$ olivine phenocrysts (completely altered to iddingsite; maximum size $=4 \mathrm{~mm}$, modal size $=$ $2 \mathrm{~mm}$ ) and $3 \%$ augite phenocrysts (unaltered; maximum size $=5 \mathrm{~mm}$, modal size $=2.5 \mathrm{~mm}$ ). The groundmass is fine grained and moderately altered, with $0 \%-5 \%$ vesicles (moderate sphericity, 
rounded) and carbonate-filled veins. Two Type 2 clasts were found.

- Type 3 (Subunit IIA): aphyric basalt that is mottled brown with no phenocrysts. The groundmass is fine grained and moderately to highly altered, with $10 \%$ vesicles (high sphericity, rounded) and veins filled with brown clay and carbonate. One Type 3 clast was found.

- Type 4 (Subunit IIA): moderately augite-olivineplagioclase-phyric basalt that is mottled graycream brown, with $3 \%$ olivine phenocrysts (altered to iddingsite and carbonate; maximum size $=3 \mathrm{~mm}$, modal size $=1 \mathrm{~mm}), 5 \%$ augite phenocrysts (unaltered; maximum size $=4 \mathrm{~mm}$, modal size $=2 \mathrm{~mm}$ ), and $3 \%$ plagioclase (altered; maximum size $=2 \mathrm{~mm}$, modal size $=1 \mathrm{~mm}$ ). The groundmass is fine grained and highly altered, with $1 \%$ vesicles (high sphericity, rounded) and veins filled with brown clay. One Type 4 clast was found.

- Type 5 (Subunit IIA): highly olivine-augite-phyric basalt that is medium gray-orange, with $25 \%$ olivine phenocrysts (altered to iddingsite and carbonate; maximum size $=5.5 \mathrm{~mm}$, modal size $=2 \mathrm{~mm}$ ) and $5 \%$ augite phenocrysts (unaltered; maximum size $=6 \mathrm{~mm}$, modal size $=3 \mathrm{~mm}$ ). The groundmass is fine grained and highly altered, with $0 \%-3 \%$ vesicles (moderate sphericity, rounded) and carbonate-filled veins. One Type 5 clast was found.

\section{Hole U1375B}

\section{Lithologic and stratigraphic igneous units Unit I}

Interval: 330-U1375B-1R-1, 0-57 cm

Depth: 0-0.57 mbsf

Lithology: moderately olivine-augite-phyric microgabbro (dolerite)

Lithologic unit: 1

Unit I is $57 \mathrm{~cm}$ thick and composed of moderately olivine-augite-phyric microgabbro (dolerite) distinguished from basalt by its groundmass grain size of $>1 \mathrm{~mm}$ (Samples 330-U1375B-1R-1, 1-3 cm [Thin Section 227], and 1R-1, 56-57 cm [Thin Section 228]) (Fig. F7). This holocrystalline, moderately porphyritic rock was the only medium-grained igneous rock recovered during Expedition 330. It contains 2\% altered olivine phenocrysts (up to $10 \mathrm{~mm}$ ) and $0.8 \%$ fresh augite phenocrysts (up to $15 \mathrm{~mm}$ ). The groundmass is composed of tabular plagioclase crystals, olivine, titanaugite, and accessory apatite (Fig. F7C, F7D).

\section{Interpretation of the igneous succession}

The microgabbro in Hole U1375B is the only igneous rock drilled at Site U1375 that might be in situ. However, because neither contact was recovered, it is not possible to determine whether the drilled interval is from a large clast in a sedimentary deposit or part of a basement intrusion exposed at the surface by erosion.

\section{Alteration petrology}

One sedimentary unit containing different types of volcanic clasts was identified in Hole U1375A, and one igneous unit (microgabbro) was recovered in Hole U1375B (see "Igneous petrology and volcanology"). Sections from both holes have undergone alteration by low-temperature water-rock interactions or weathering.

\section{Alteration phases}

Alteration at Site U1375 in both the volcanic clasts from Hole U1375A and the microgabbro from Hole $\mathrm{U} 1375 \mathrm{~B}$ has mainly resulted in the replacement of olivine. In contrast, plagioclase and augite are generally well preserved, both as phenocrysts and in the groundmass within the clasts. Plagioclase shows minor alteration to sericite/illite in some rocks but characteristically is fresh. Olivine is typically completely altered to iddingsite (Fig. F8B), hematite, Fe oxyhydroxides, and carbonates.

\section{Overall alteration characteristics of Hole U1375A}

The overall alteration of the volcanic clasts in sedimentary units from Hole U1375A ranges from slight to high (10\%-60\%), as estimated from core descriptions and thin section observations. Pervasive alteration gave a yellow/orange to brownish-gray color to the clasts. Nevertheless, two clasts are dark gray (Sample 330-U1375A-2R-1, 42-46 cm) to light greenish gray (Sample 2R-1, 81-100 cm).

No vesicles were identified in these clasts. Veins are mainly filled with carbonate and brown clay. Some of the clasts have brown halos associated with veins and fractures. Such halos, commonly found in permeable basaltic formations such as breccia, are related to the alteration of basalts by bottom seawater percolating through the oceanic basement (halmyrolysis), which takes place at water temperatures of $<2^{\circ} \mathrm{C}$ and under large water/rock ratios and oxidizing conditions (Mahoney, Fitton, Wallace, et al., 2001). 


\section{Overall alteration characteristics of Hole U1375B}

The moderately olivine-augite-phyric microgabbro (dolerite) from Hole U1375B shows moderate to high (55\%) alteration and has an orange to dark gray color. Olivine is altered to hematite, iddingsite, and some oxyhydroxides (Fig. F8B). The microgabbro contains strongly oxidized millimeter-thick veins (Fig. F8A). Two types of veins were identified. The thicker ones are mostly filled with goethite (Fig. F9E, F9F), whereas the thinner veins are coated by goethite on the walls and filled with carbonate (Figs. F8C, F9C, F9D). A few veins were first filled with green clay minerals and then later with goethite (Fig. F9A, F9B).

\section{Structural geology}

Structural features in Hole U1375A on Achernar Guyot are veins and vein networks in sedimentary clasts and geopetals in the surrounding sediment. Seven geopetal structures were observed: two are horizontal (Fig. F10A, F10B) and the other five have angles from $4^{\circ}$ to $26^{\circ}$ from horizontal (e.g., Fig. F10C). Importantly, these dipping geopetals show evidence for water flow during or after geopetal sediment deposition. For example, the level of sediment on either side of a small clast is not equal (blue arrow in Fig. F10C). This suggests significant water flow from right to left, which would have locally disturbed the deposition of these sediments or caused some erosion of the fine-grained sediments. In the same example, the left sides of the larger clasts also lack fine-grained yellowish sediment, suggesting scouring by water flowing from right to left. It can be concluded that these five anomalous geopetals were not originally deposited horizontally and therefore do not yield accurate information about the paleohorizontal level of deposition. In contrast, the sediments around the two horizontal geopetals in the same core show no evidence for being disturbed by water flow (Fig. F10A, F10B). From the presently horizontal nature of these two "undisturbed" geopetals, it can be concluded that this part of Achernar Guyot has not been tilted since deposition of the geopetal material.

Several of the larger clasts in Hole U1375A contain common veins and vein networks as wide as $8 \mathrm{~mm}$, although typically much thinner. Because these veins were formed before erosion and redeposition of the clasts, the present orientation of the veins has no geologic significance. No orientation measurements were taken on these features. Vein widths and infilling materials are discussed in "Alteration petrology."
In Hole U1375B, 12 veins were recorded in the $57 \mathrm{~cm}$ of microgabbro (dolerite) recovered. These veins are dominantly steeply dipping, with a pronounced maximum of $70^{\circ}-75^{\circ}$ (Fig. F11A, F11B). There is also a conjugate set of three veins that have a much shallower orientation of $\sim 20^{\circ}$ (Fig. F11A, F11B). These primary and conjugate veins may represent infilled fractures that formed by decompression during erosion of this intrusive rock. If this is indeed the case, the orientation of primary and conjugate veins is indirect evidence that this microgabbro may be in situ, rather than a large boulder in the top sediment cover of Achernar Guyot.

\section{Summary}

Only two reliable geopetals were observed in Hole U1375A. These geopetals have horizontal orientations, indicating that Achernar Guyot has not been tilted since deposition of the geopetal sediments. Several veins and vein networks as wide as $8 \mathrm{~mm}$ are also present in the sedimentary clasts of Hole U1375A. Within the microgabbro of Hole U1375B, 12 veins were observed. The predominant orientation of these veins is $70^{\circ}-75^{\circ}$, with thinner conjugate veins at $20^{\circ}$.

\section{Geochemistry Igneous rocks}

One sample of the microgabbro from Hole U1375B (Unit I) was analyzed for major elements and several trace elements (Table T6) by inductively coupled plasma-atomic emission spectroscopy (see "Geochemistry" in the "Methods" chapter [Expedition 330 Scientists, 2012a] for information on analytical procedures, instrumentation, and data quality).

The major element oxides total only $95.68 \mathrm{wt} \%$. Possible reasons for totals significantly different from $100 \mathrm{wt} \%$ are discussed in "Geochemistry" in the "Methods" chapter [Expedition 330 Scientists, 2012a]. As with other Expedition 330 analyses, we normalized the raw major element values to 100 $\mathrm{wt} \%$ totals. The normalized values are presented below the raw data in Table T6 and are used in geochemistry figures in the "Site U1376" chapter (Expedition 330 Scientists, 2012c) and in the discussion below.

Despite abundant veining in the microgabbro (see "Alteration petrology"), the sample chosen for analysis is only moderately altered, as indicated by a weight loss on ignition value of $1.4 \mathrm{wt} \%$. Data for the sample fall in the field of basanite and tephrite on a total alkalis $\left(\mathrm{Na}_{2} \mathrm{O}+\mathrm{K}_{2} \mathrm{O}\right)$ vs. $\mathrm{SiO}_{2}$ diagram (see Fig. F38 in the "Site U1376" chapter [Expedition 330 
Scientists, 2012c]). With a total alkali content of 5.34 wt $\%$ and $\mathrm{a} \mathrm{SiO}_{2}$ concentration of $44.33 \mathrm{wt} \%$, this sample is one of the most alkalic rocks recovered during Expedition 330. It is also one of the more evolved, with an $\mathrm{Mg}$ number $\left(\mathrm{Mg \#}=100 \times \mathrm{Mg}^{2+} /\right.$ $\left[\mathrm{Mg}^{2+}+\mathrm{Fe}^{2+}\right]$, assuming $\mathrm{Fe}_{2} \mathrm{O}_{3} / \mathrm{FeO}=0.15$ ) of 38.2 and $\mathrm{MgO}, \mathrm{Ni}$, and $\mathrm{Cr}$ contents of $3.84 \mathrm{wt} \%, 60 \mathrm{ppm}$, and 39 ppm, respectively. In an $\mathrm{Al}_{2} \mathrm{O}_{3}$ vs. MgO diagram, the data point for this sample lies near the high- $\mathrm{Al}_{2} \mathrm{O}_{3}$, low-MgO end of the array defined by the other Expedition 330 rocks (see Fig. F39A in the "Site U1376" chapter [Expedition 330 Scientists, 2012c]). This array is consistent with olivine being the major control on magmatic differentiation (see "Geochemistry" in the "Site U1372" chapter [Expedition 330 Scientists, 2012b]). The sample also has a rather low Sc concentration (17 ppm) and relatively low $\mathrm{CaO} /$ $\mathrm{Al}_{2} \mathrm{O}_{3}$ ratio (0.64; see Fig. F39B in the "Site U1376" chapter [Expedition 330 Scientists, 2012c]), suggesting that fractionation of augite was also important. The relative unimportance of plagioclase during differentiation is indicated by the sample's high $\mathrm{Al}_{2} \mathrm{O}_{3}$ and Sr content (see Fig. F40B in the "Site U1376" chapter [Expedition 330 Scientists, 2012c]).

The microgabbro has the highest $\mathrm{TiO}_{2}$ concentration measured during Expedition 330 (4.46 wt\%). On diagrams of $\mathrm{TiO}_{2}$ vs. different incompatible elements, data for the sample generally lie at the high- $\mathrm{TiO}_{2} \mathrm{ex}-$ tension of the arrays defined by other Expedition 330 rocks (see Fig. F40A-F40C in the "Site U1376" chapter [Expedition 330 Scientists, 2012c]). However, $\mathrm{Y}$ and $\mathrm{Zr}$ concentrations are slightly low for the sample's $\mathrm{TiO}_{2}$ content (e.g., Fig. F41D in the "Site U1376" chapter [Expedition 330 Scientists, 2012c]). With $259 \mathrm{ppm} \mathrm{Zr}$, the rock is probably unsaturated in zircon and is unlikely to have lost zircon, or a more exotic Zr-Y-rich phase, by crystal fractionation. Instead, the Hole U1375B microgabbro may represent a different magma type than those seen at Sites U1372-U1374 or U1376.

\section{Carbon, organic carbon, nitrogen, and carbonate}

No samples from Site U1375 were analyzed for carbonate, total carbon, total organic carbon, or total nitrogen content.

\section{Physical properties}

Characterization of physical properties was conducted on cores recovered from Holes U1375A and U1375B at Achernar Guyot. The whole-round core sections (two from Hole U1375A and one from Hole
U1375B) were run through the Whole-Round Multisensor Logger (WRMSL) for measurement of gamma ray attenuation (GRA) bulk density and magnetic susceptibility. The three whole-round core sections were also run through the Natural Gamma Radiation Logger (NGRL). The archive-half split-core sections were then run through the Section Half Multisensor Logger (SHMSL) for measurement of laser height, color reflectance, and point magnetic susceptibility. One discrete oriented rock cube was sampled from interval 330-U1375B-1R-1W, 43-45 cm, for compressional wave ( $P$-wave) velocity (in three orthogonal directions), as well as moisture and density measurements. This sample was also used for paleomagnetic measurements of alternating-field demagnetization (see "Paleomagnetism"). Because of equipment failure, no measurements of thermal conductivity were made at this site (see "Physical properties" in the "Methods" chapter [Expedition 330 Scientists, 2012a]).

\section{Whole-Round Multisensor Logger measurements}

Throughout the lithified sediments and breccia of Hole U1375A and the igneous rocks of Hole U1375B the core is fractured and broken, as is typical of hard rock coring. These discontinuities in the recovered core led to spurious values in the data collected from the WRMSL and SHMSL, so we applied a data filtering and processing algorithm to remove the affected data (see "Physical properties" in the "Methods" chapter [Expedition 330 Scientists, 2012a]). In this report we show only the filtered data; for raw data we refer the reader to the visual core descriptions (see "Core descriptions") and the Laboratory Information Management System (LIMS) database (iodp.tamu.edu/tasapps/).

\section{Magnetic susceptibility}

Whole-round magnetic susceptibility measurements for the two holes from Site U1375 are shown in Figure F12. Magnetic susceptibility is sensitive to the mineralogical composition of the rock. In Hole U1375A magnetic susceptibility averages $5.13 \times 10^{-3}$ SI. Two intervals of moderately higher values up to $1.10 \times 10^{-2}$ SI were observed, and these correspond with the locations of basaltic clasts that appear less altered than elsewhere in the hole. The lithified sediment toward the bottom of the hole between 9.6 and 10 mbsf has the lowest magnetic susceptibility, with an average of $9.6 \times 10^{-4}$ SI. In contrast, the igneous microgabbro observed throughout Hole U1375B has a much higher average magnetic susceptibility of $2.30 \times 10^{-2}$ SI. 


\section{Gamma ray attenuation bulk density}

The results of GRA-derived bulk density for the two holes are shown in Figure F12. A correction factor of 1.138 was applied to account for the smaller diameter $(58 \mathrm{~mm})$ of hard rock material compared to the full $66 \mathrm{~mm}$ diameter of the core liner (see "Physical properties" in the "Methods" chapter [Expedition 330 Scientists, 2012a]). Values of $<1.00 \mathrm{~g} / \mathrm{cm}^{3}$ were attributed to empty portions of core liner and removed. The average GRA-derived bulk densities in Holes U1375A and U1375B are $2.26 \mathrm{~g} / \mathrm{cm}^{3}$ and 2.69 $\mathrm{g} / \mathrm{cm}^{3}$, respectively. A decrease in GRA-derived bulk density from an average of $2.37 \mathrm{~g} / \mathrm{cm}^{3}$ above 9.5 mbsf to $1.90 \mathrm{~g} / \mathrm{cm}^{3}$ below was observed in Hole U1375A. This trend is likely a combination of two factors: a downhole-decreasing amount of basalt clasts and the effect of the recovered rock deviating significantly from a cylindrical shape toward the bottom of the hole. These noncylindrical pieces have less volume than is assumed in the density calculation, even after the application of the correction factor for hard rock cores.

\section{Natural Gamma Radiation Logger}

Natural gamma radiation (NGR) measurements reflect the amount of uranium, thorium, and potassium present in the rock. Results from the NGRL are shown in Figure F12. For Hole U1375A, NGR ranges from 7.18 to 26.00 counts per second (cps), with a trend of decreasing values downhole. This trend likely results from a decrease in basalt clasts but may also be affected by the decreased volume of rocks recovered toward the bottom of the hole. NGR values from Hole U1375B are consistent, averaging 22.13 cps.

\section{Section Half Multisensor Logger measurements}

\section{Color reflectance spectrometry}

Color reflectance spectrometry results summarized in Figure F12 include L* (lightness of the recovered core) and $\mathrm{a}^{*}$ and $\mathrm{b}^{*}$ (redness vs. greenness and yellowness vs. blueness, respectively). Cores from both holes generally have more yellow- than blue-colored spectra. Hole U1375A exhibits a distinctly red spectrum, whereas Hole U1375B has neutral to slightly red values.

\section{Point magnetic susceptibility}

Point magnetic susceptibility results are shown in Figure F12 along with whole-round magnetic susceptibility data. Both data sets agree well. Hole U1375A has an average point magnetic susceptibility of 2.50 $\times 10^{-3} \mathrm{SI}$, and Hole U1375B has an average of $2.13 \times$ $10^{-2} \mathrm{SI}$.

\section{Moisture and density}

Only one discrete sample was taken from Site U1375 (Sample 330-U1375B-1R-1W, 43-45 cm). This sample represents the microgabbro recovered in Hole $\mathrm{U} 1375 \mathrm{~B}$ and is characterized by a bulk density of $2.85 \mathrm{~g} / \mathrm{cm}^{3}$ and a porosity of $4.4 \%$. The bulk density value is comparable to nearby GRA-derived bulk density measurements, which vary from 2.66 to 2.90 $\mathrm{g} / \mathrm{cm}^{3}$. Results of the full moisture and density determinations on this sample, including bulk density, dry density, grain density, void ratio, water content, and porosity, are listed in Table T7.

\section{Compressional wave ( $P$-wave) velocity}

Compressional wave ( $P$-wave) velocity was measured on discrete Sample 330-U1375B-1R-1W, 43-45 cm, in three orthogonal directions: along the $x$-axis normal to the split-core surface, along the $y$-axis parallel to the split-core surface, and along the $z$-axis downcore. Measured values are 6.074, 5.954, and 6.095 $\mathrm{km} / \mathrm{s}$, respectively, with an average of $6.041 \mathrm{~km} / \mathrm{s}$ (Table T7).

\section{Paleomagnetism} Hole U1375A

No paleomagnetic experiments were conducted on Core 330-U1375A-1R.

\section{Hole U1375B}

Archive-half core remanent magnetization data

The natural remanent magnetization (NRM) of the archive half of Core 330-U1375B-1R was measured at $2 \mathrm{~cm}$ intervals in the cryogenic magnetometer and progressively demagnetized in an alternating field (AF) at steps of 10, 15, 20, 25, 30, 40, 50, and $70 \mathrm{mT}$. After filtering out data near the piece ends, 10 measurements remained. Of these measurements, five were from Piece 2 and five were from Piece 5. Because there were so few data, the principal component analysis (PCA) directions were picked by hand. Of these, $50 \%$ had a maximum angular deviation of $<5^{\circ}$. Fisher statistics were used to calculate the mean inclination (as opposed to inclination-only statistics) because all the reliable measurements were from a single piece (Piece 2) and the declinations suggest the constituent subpieces did not rotate relative to each other. The resulting inclination is $36.3^{\circ} \pm 1.6^{\circ}$ (circular standard deviation), indicating reversed polarity in the Southern Hemisphere. However, no up- 
per or lower boundaries to this microgabbro unit were recovered, and therefore the in situ confidence index (see "Igneous petrology and volcanology" in the "Methods" chapter [Expedition 330 Scientists, 2012a]) was determined to be not applicable (NA).

\section{Discrete sample remanent magnetization data}

Only one discrete sample was taken from the microgabbro (dolerite) of Core 330-U1375B-1R, at 43-45 $\mathrm{cm}$. The NRM and bulk magnetic susceptibility of this sample are $1.41 \mathrm{~A} / \mathrm{m}$ and $4.07 \times 10^{-2} \mathrm{SI}$, respectively, yielding a Königsberger ratio $(Q n)$ of 0.95 . The sample was subjected to stepwise AF demagnetization, but unfortunately a large spurious magnetization, probably of anhysteretic or isothermal origin, was unexpectedly imparted during demagnetization at low field levels $(<10 \mathrm{mT})$. Despite further AF treatment at higher fields, an original remanent magnetization component could not be confidently isolated. Nevertheless, clustering of magnetization vectors about a northwest and downward direction (in geographic coordinates) was observed at treatments of $30 \mathrm{mT}$ and above. This direction is broadly consistent with the AF demagnetization results from the archive-half cores.

\section{References}

Beier, C., Vanderkluysen, L., Regelous, M., Mahoney, J.J., and Garbe-Schönberg, D., 2011. Lithospheric control on geochemical composition along the Louisville Seamount Chain. Geochem., Geophys., Geosyst., 12:Q0AM01. doi:10.1029/2011GC003690

Cheng, Q., Park, K.-H., Macdougal, J.D., Zindler, A., Lugmair, G.W., Hawkins, J., Lonsdale, P., and Staudigel, H., 1987. Isotopic evidence for a hot spot origin of the Louisville Seamount Chain. In Keating, B.H., Fryer, P., Batiza, R., and Boehlert, G. (Eds.), Seamounts, Islands and Atolls. Geophys. Monogr., 43:283-296.

Courtillot, V., Davaille, A., Besse, J., and Stock, J., 2003. Three distinct types of hotspots in Earth's mantle. Earth Planet. Sci. Lett., 205(3-4):295-308. doi:10.1016/S0012821X(02)01048-8

Duncan, R.A., Tarduno, J.A., and Scholl, D.W., 2006. Leg 197 synthesis: southward motion and geochemical variability of the Hawaiian hotspot. In Duncan, R.A., Tarduno, J.A., Davies, T.A., and Scholl, D.W. (Eds.), Proc. ODP, Sci. Results, 197: College Station, TX (Ocean Drilling Program), 1-39. doi:10.2973/

odp.proc.sr.197.001.2006

Expedition 330 Scientists, 2012a. Methods. In Koppers, A.A.P., Yamazaki, T., Geldmacher, J., and the Expedition 330 Scientists, Proc. IODP, 330: Tokyo (Integrated Ocean Drilling Program Management International, Inc.). doi:10.2204/iodp.proc.330.102.2012
Expedition 330 Scientists, 2012b. Site U1372. In Koppers, A.A.P., Yamazaki, T., Geldmacher, J., and the Expedition 330 Scientists, Proc. IODP, 330: Tokyo (Integrated Ocean Drilling Program Management International, Inc.). doi:10.2204/iodp.proc.330.103.2012

Expedition 330 Scientists, 2012c. Site U1376. In Koppers, A.A.P., Yamazaki, T., Geldmacher, J., and the Expedition 330 Scientists, Proc. IODP, 330: Tokyo (Integrated Ocean Drilling Program Management International, Inc.). doi:10.2204/iodp.proc.330.107.2012

Hawkins, J.W., Lonsdale, P., and Batiza, R., 1987. Petrologic evolution of the Louisville Seamount Chain. In Keating, B.H., Fryer, P., Batiza, R., and Boehlert, G.W. (Eds.), Seamounts, Islands, and Atolls. Geophys. Monogr., 43:235254.

Koppers, A.A.P., Duncan, R.A., and Steinberger, B., 2004. Implications of a nonlinear ${ }^{40} \mathrm{Ar} /{ }^{39} \mathrm{Ar}$ age progression along the Louisville Seamount Trail for models of fixed and moving hot spots. Geochem., Geophys., Geosyst., 5(6):Q06L02. doi:10.1029/2003GC000671

Koppers, A.A.P., Yamazaki, T., and Geldmacher, J., 2010. Louisville Seamount Trail: implications for geodynamic mantle flow models and the geochemical evolution of primary hotspots. IODP Sci. Prosp., 330. doi:10.2204/ iodp.sp.330.2010

Mahoney, J.J., Fitton, J.G., Wallace, P.J., et al., 2001. Proc. ODP, Init. Repts., 192: College Station, TX (Ocean Drilling Program). doi:10.2973/odp.proc.ir.192.2001

Murdmaa, I., Nemliher, J., Bogdanova, O., Gorshkov, A., Kallaste, T., and Vasilyeva, V., 1995. Ferromanganese and phosphatic hardgrounds on the western Pacific guyots drilled during Legs 143 and 144. In Haggerty, J.A., Premoli Silva, I., Rack, F., and McNutt, M.K. (Eds.), Proc. ODP, Sci. Results, 144: College Station, TX (Ocean Drilling Program), 419-428. doi:10.2973/ odp.proc.sr.144.070.1995

Smith, W.H.F., and Sandwell, D.T., 1997. Global sea floor topography from satellite altimetry and ship depth soundings. Science, 277(5334):1956-1962. doi:10.1126/ science.277.5334.1956

Steinberger, B., 2002. Motion of the Easter hot spot relative to Hawaii and Louisville hot spots. Geochem., Geophys., Geosyst., 3(11):8503-8529. doi:10.1029/ 2002GC000334

Steinberger, B., and Antretter, M., 2006. Conduit diameter and buoyant rising speed of mantle plumes: implications for the motion of hot spots and shape of plume conduits. Geochem., Geophys., Geosyst., 7(11):Q11018Q11042. doi:10.1029/2006GC001409

Steinberger, B., and Calderwood, A., 2006. Models of largescale viscous flow in the Earth's mantle with constraints from mineral physics and surface observations. Geophys. J. Int., 167(3):1461-1481. doi:10.1111/j.1365246X.2006.03131.X

Steinberger, B., Sutherland, R., and O'Connell, R.J., 2004. Prediction of Emperor-Hawaii Seamount locations from a revised model of global plate motion and mantle flow. Nature (London, U. K.), 430(6996):167-173. doi:10.1038/nature02660 
Tarduno, J.A., Duncan, R.A., Scholl, D.W., Cottrell, R.D., Steinberger, B., Thordarson, T., Kerr, B.C., Neal, C.R., Frey, F.A., Torii, M., and Carvallo, C., 2003. The Emperor Seamounts: southward motion of the Hawaiian hotspot plume in Earth's mantle. Science, 301(5636):1064-1069. doi:10.1126/science.1086442

Vanderkluysen, L., Mahoney, J.J., Koppers, A.A., and Lonsdale, P.F., 2007. Geochemical evolution of the Louisville Seamount Chain. Eos, Trans. Am. Geophys. Union,
88(52)(Suppl.):V42B-06. http://www.agu.org/meetings/fm07/waisfm07.html

Wessel, P., and Kroenke, L.W., 1997. A geometric technique for relocating hotspots and refining absolute plate motions. Nature (London, U. K.), 387(6631):365-369. doi:10.1038/387365a0

Publication: 11 February 2012

MS 330-106 
Figure F1. Bathymetric map of the Louisville Seamount Trail in the southwest Pacific, showing the location of Site U1375 on Achernar Guyot and Site U1376 on Burton Guyot. GMT-generated bathymetric map is based on a combination of SIMRAD EM120 multibeam data collected during the AMAT02RR site survey expedition aboard the R/V Roger Revelle and global predicted bathymetry (v8.2) from Smith and Sandwell (1997). The current motion of the Pacific plate is indicated with the black arrow. The map uses a linear projection (i.e., vertical and horizontal scales differ) based on WGS-84.

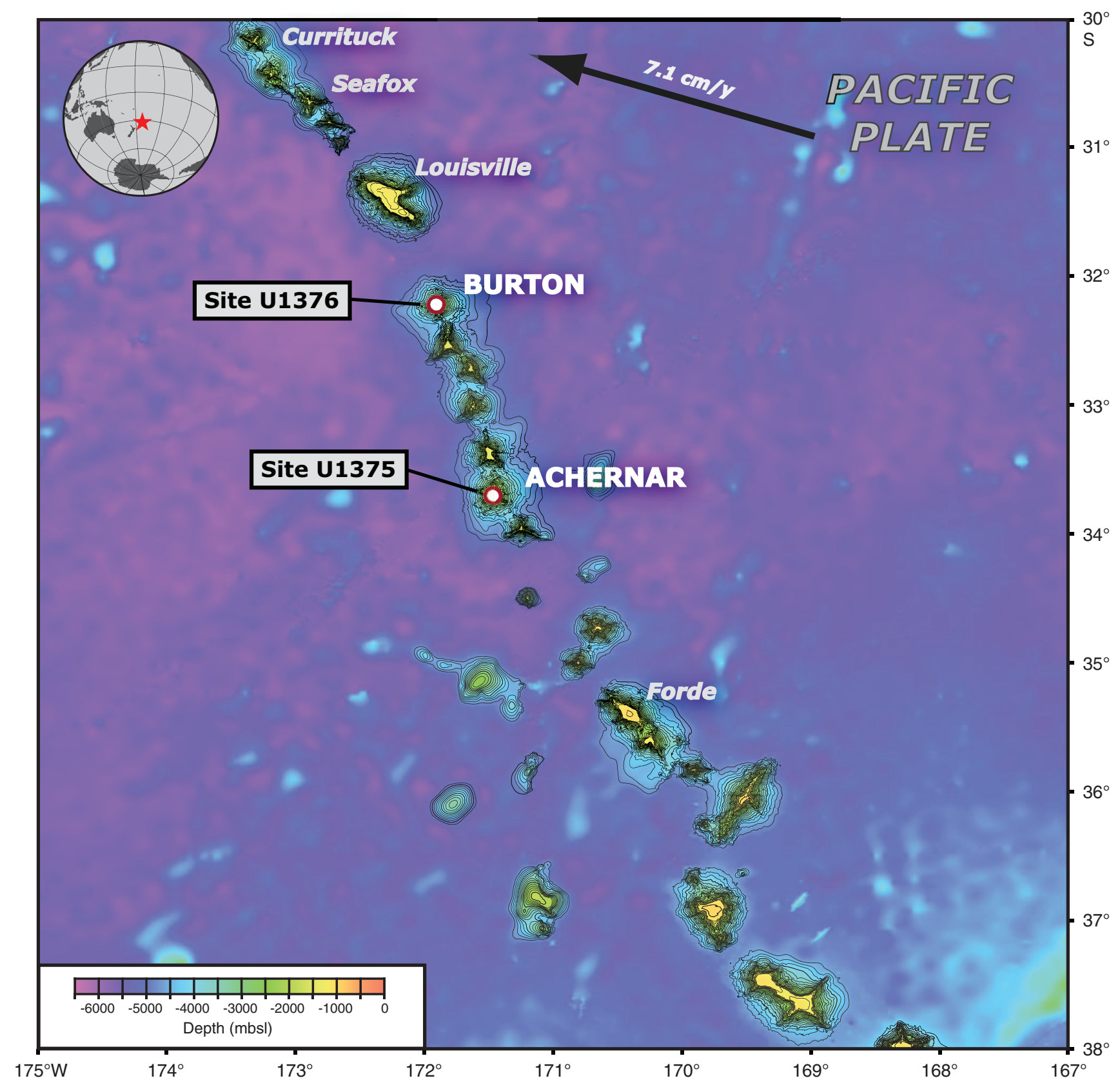


Figure F2. Detailed bathymetric map of Site U1375 on Achernar Guyot. GMT-generated bathymetric map is based on SIMRAD EM120 multibeam data collected during the AMAT02RR site survey expedition aboard the R/V Roger Revelle and global predicted bathymetry (v8.2) from Smith and Sandwell (1997). Dredge locations from previous cruises are indicated by open squares. Crossing multichannel seismic reflection lines collected during the AMAT02RR site survey are shown in blue (for details, see Koppers et al., 2010). Map uses a linear projection (i.e., vertical and horizontal scales differ) based on WGS-84.

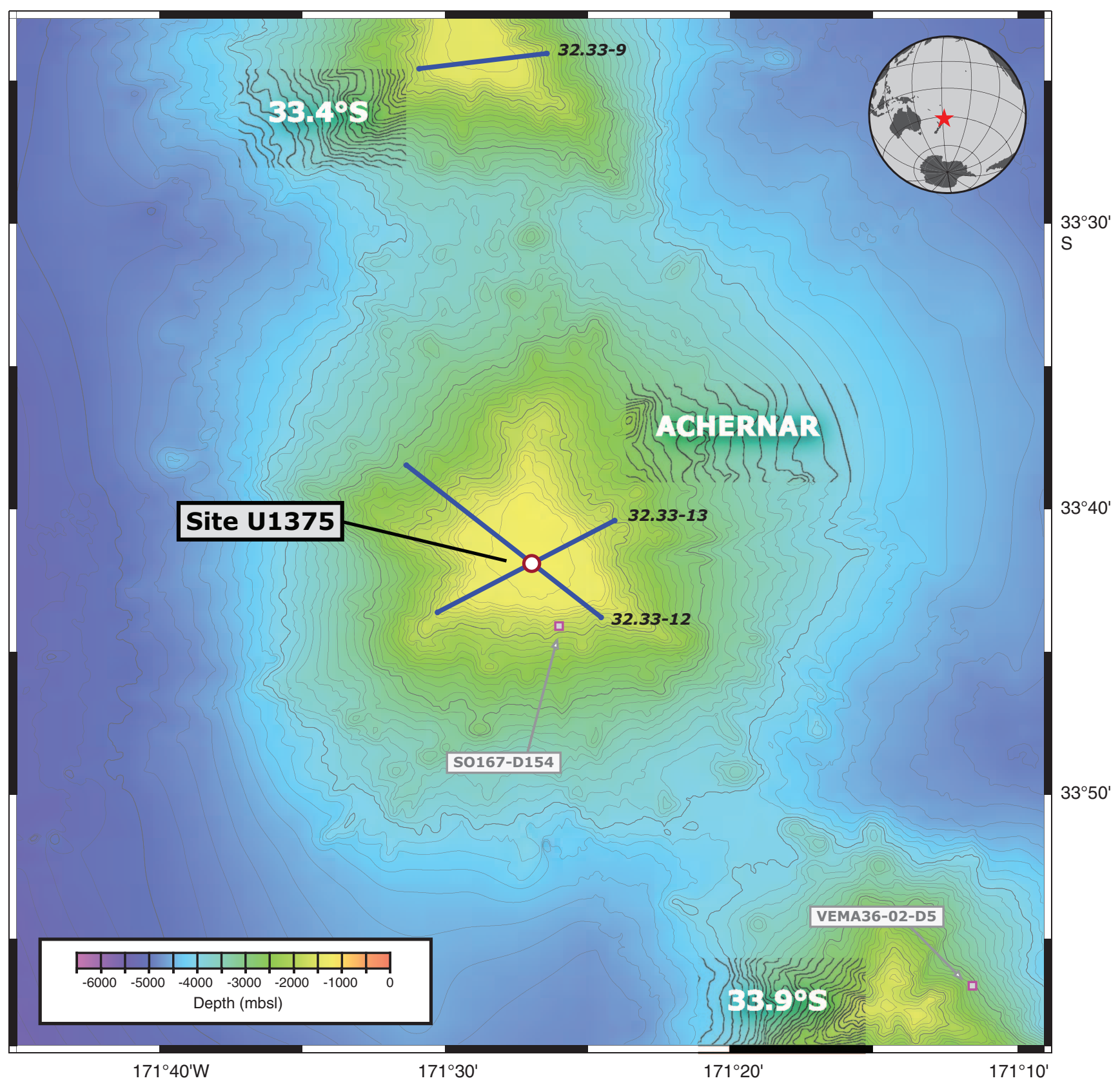


Figure F3. Stratigraphic summary of sedimentary sequences, Hole U1375A. See U1375A.XLS in SIZE in SEDIMENT in "Supplementary material" for estimates of grain size and roundness with depth.

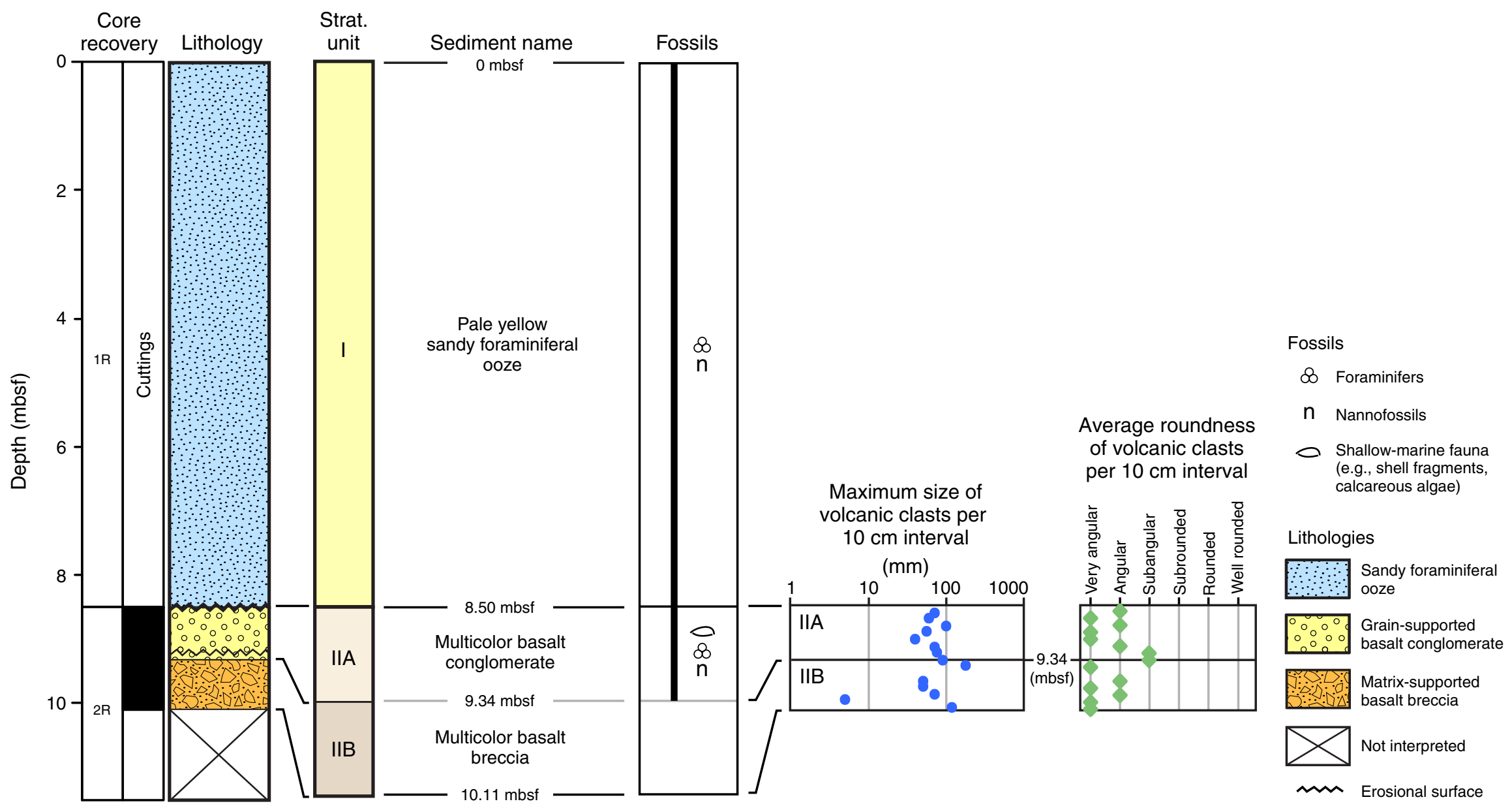


Figure F4. Close-up photographs of representative lithologies, Hole U1375A. A. Multicolor basalt conglomerate in Subunit IIA (interval 330-U1375A-2R-1A, 1-41 cm), topped by (1) ferromanganese encrustation. Interpebble and cobble spaces are composed of foraminiferal limestone, fine-grained volcaniclastic sediment, cement, and voids with (2) bioturbations and (3) geopetal structures. This subunit is interpreted as a hemipelagic interval in the sedimentary cover of Achernar Guyot. B. Multicolor basalt breccia in Subunit IIB (interval 330-U1375A-2R$1 \mathrm{~A}, 79-119 \mathrm{~cm}$ ) with (1) erosional surface. Basalt cobble with jigsaw-fit texture includes (2) calcite cement in upper border and (3) sediment infills in some cracks. This subunit is interpreted as a debris flow deposit of the sedimentary cover of Achernar Guyot.

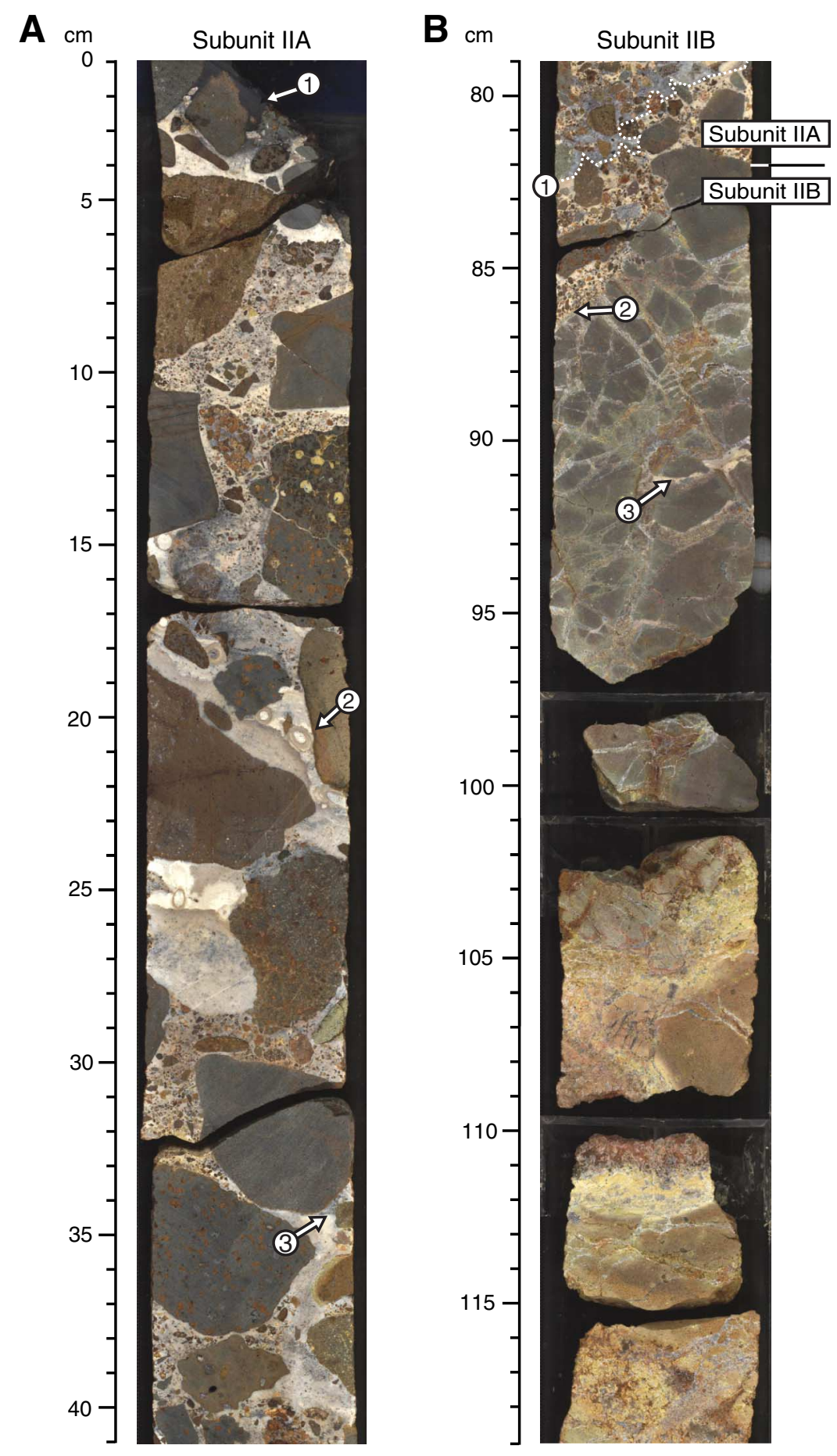


Figure F5. Calcareous nannofossil and planktonic foraminiferal biozonation, Hole U1375A. Gray shaded areas = intervals barren of age-diagnostic calcareous microfossils, wavy lines = unconformities. For legend of lithology patterns, see Figure F3.

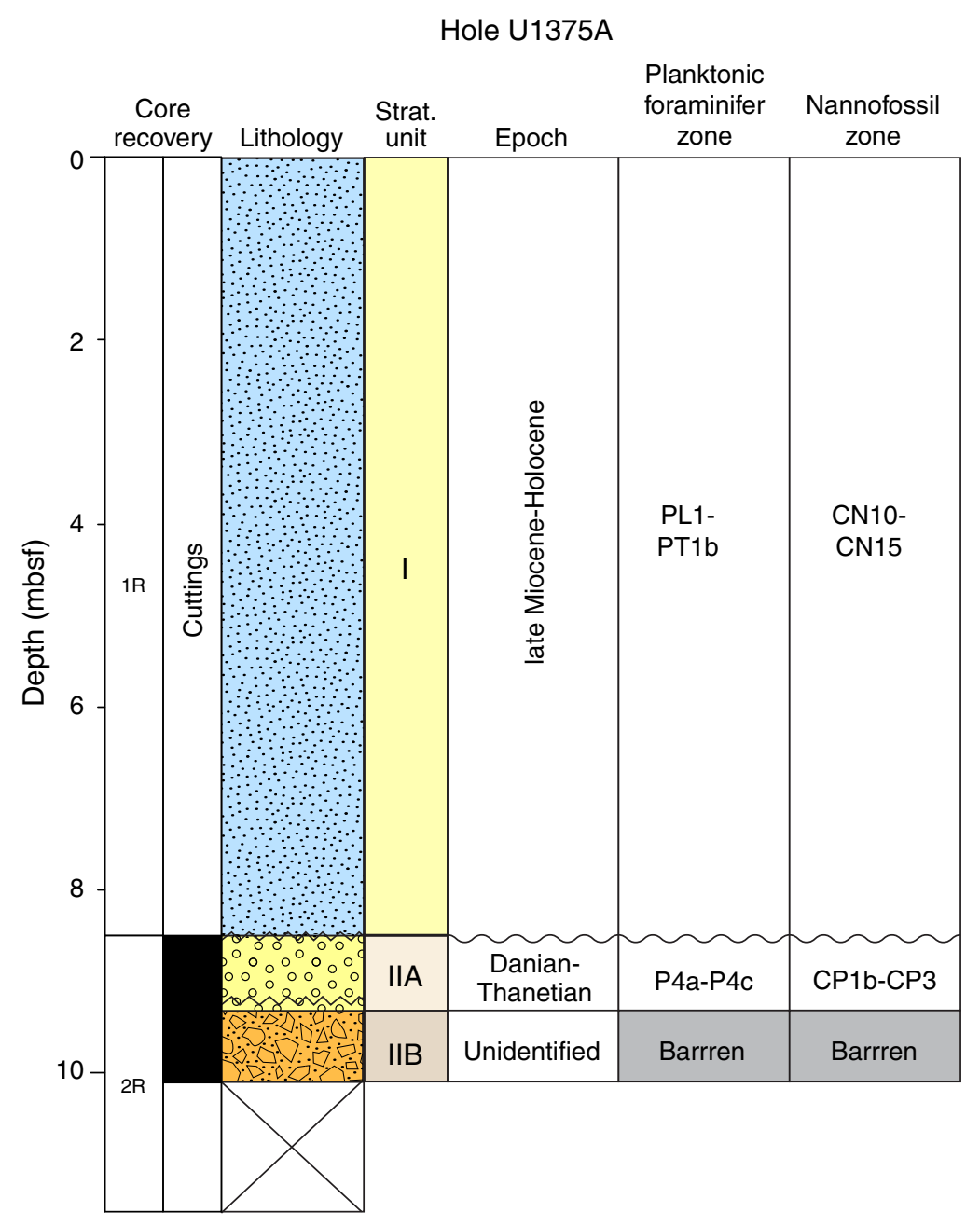


Figure F6. Thin section photomicrographs of planktonic foraminifers. A. Globanomalina cf. pseudomenardii (Sample 330-U1375A-2R-1, 26-29 cm; Thin Section 229A). B. Acarinina sp. (Sample 330-U1375A-2R-1, 26-29 $\mathrm{cm}$; Thin Section 229).
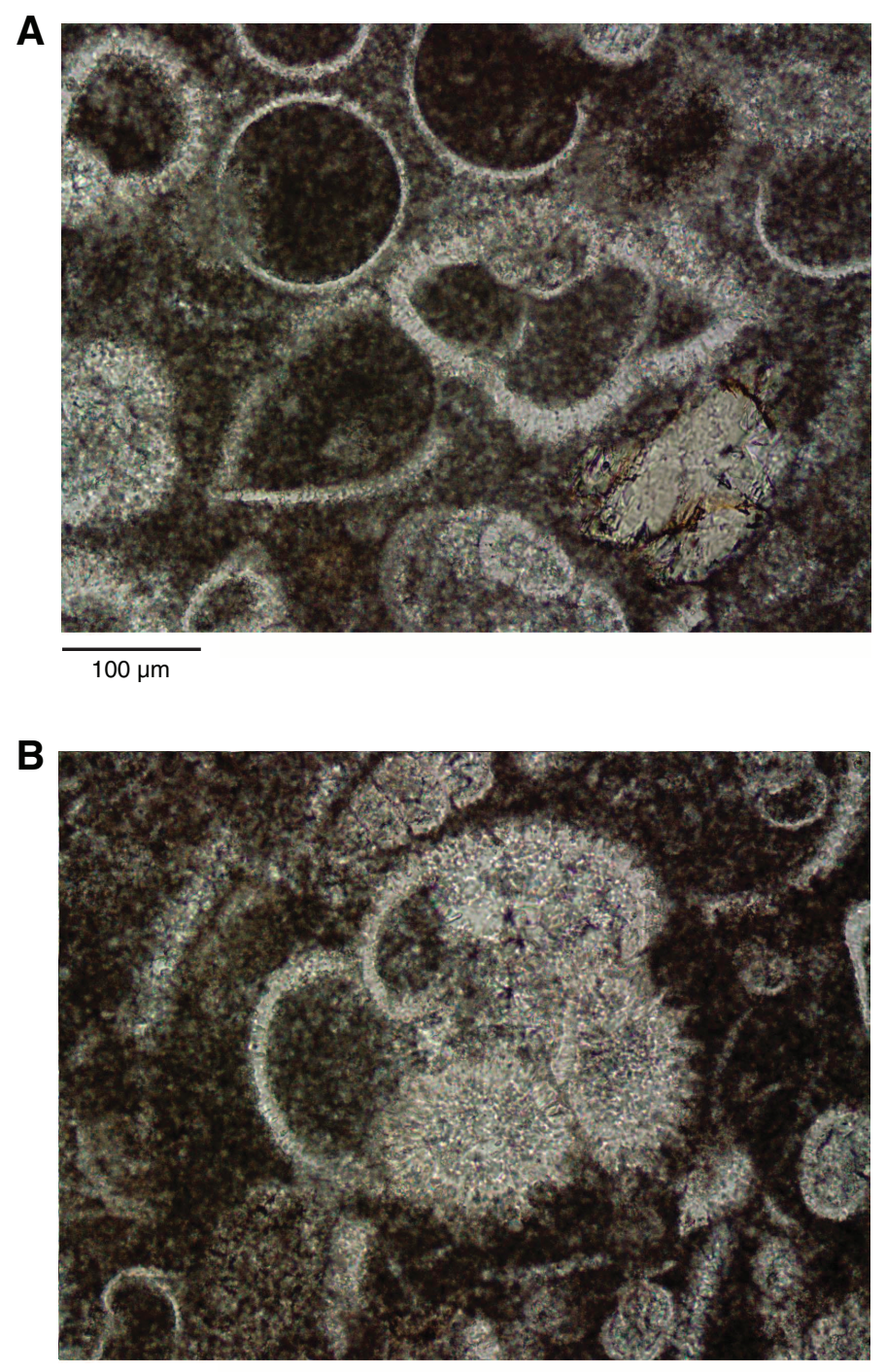

$100 \mu \mathrm{m}$ 
Figure F7. A, B. Thin section photomicrographs of moderately olivine-augite-phyric microgabbro from Unit I (Sample 330-U1375B-1R-1W, 1-3 cm; Thin Section 227): (A) plane-polarized light, (B) crossed polars. C, D. Close-up of moderately porphyritic intergranular holocrystalline texture (Sample 330-U1375B-1R-1W, 56-57 cm; Thin Section 228): (C) plane-polarized light, (D) crossed polars. Groundmass texture is characterized by tabular plagioclase with anhedral crystals of augite in the interstices.

A

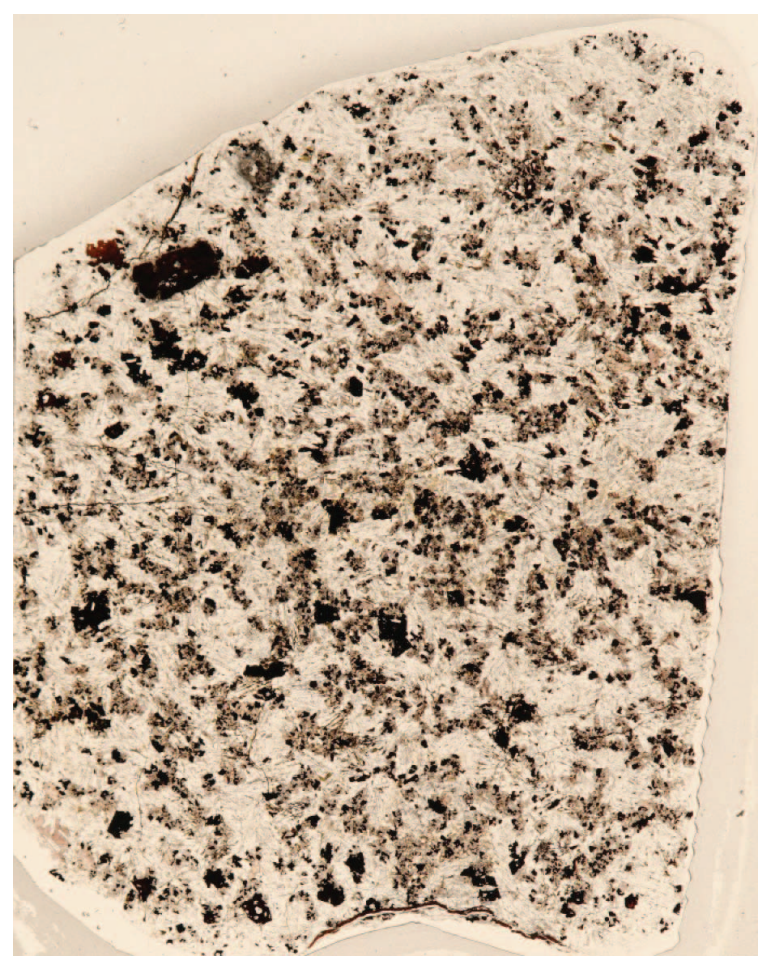

$10 \mathrm{~mm}$

\section{C}

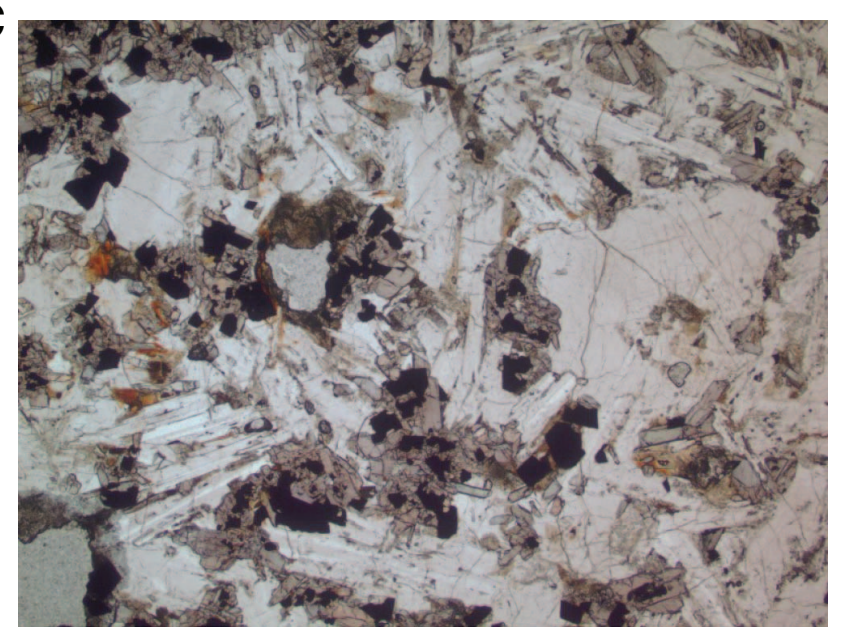

$1 \mathrm{~mm}$
B

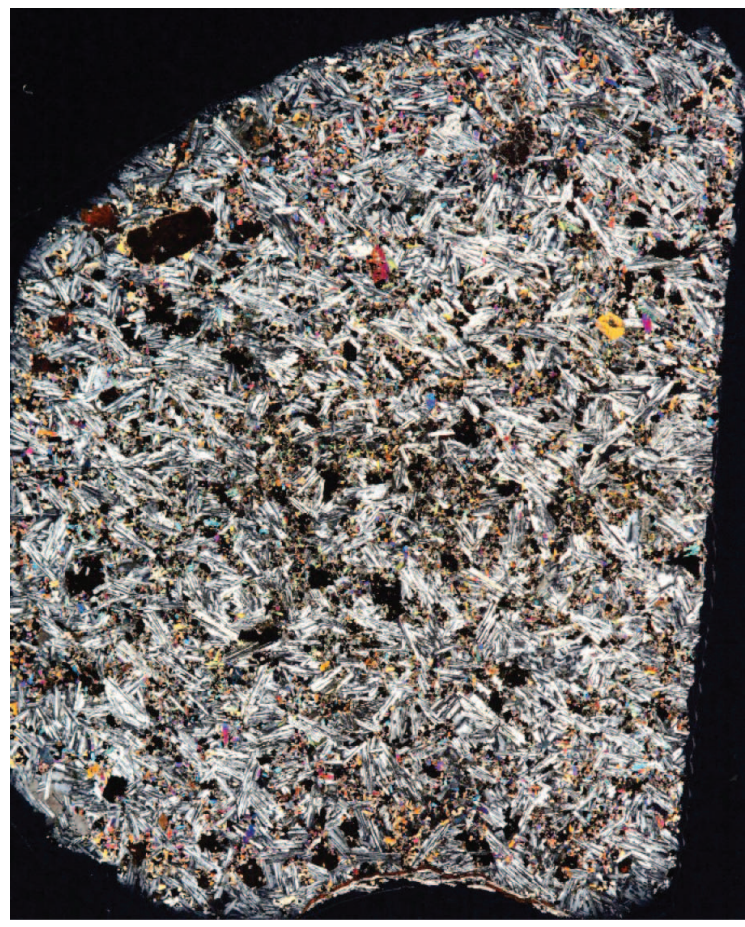

$10 \mathrm{~mm}$

D

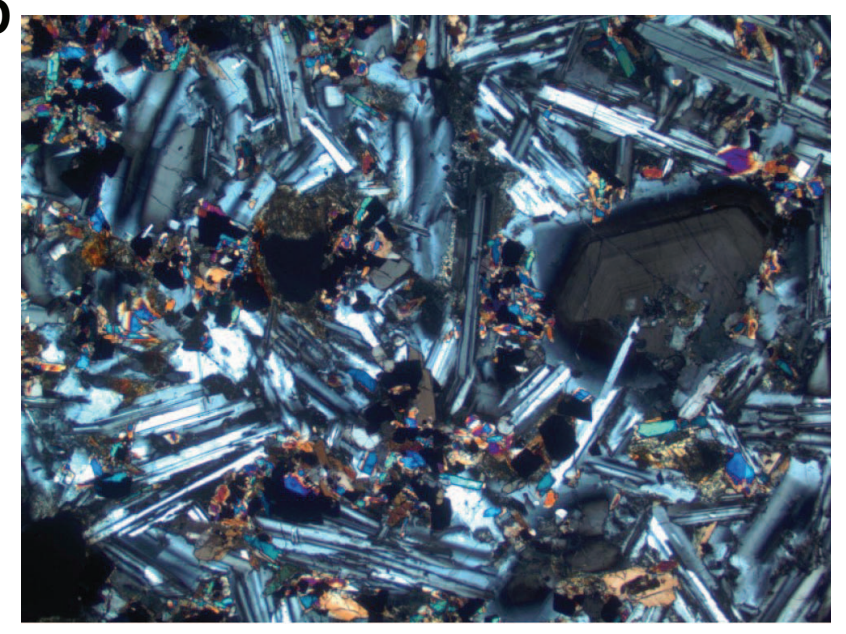

$1 \mathrm{~mm}$ 
Figure F8. A. Close-up photograph of Thin Section 228 (Sample 330-U1375B-1R-1, 57-59 cm), showing a reddish-brown vein (from left to right) filled with goethite and another vein (from top to bottom) mostly filled with carbonate and some goethite (right-hand side of image). B. Thin section photomicrograph of completely altered microcrystals of olivine to hematite, iddingsite, and some Fe oxyhydroxides (moderately olivine-augitephyric microgabbro) (Sample 330-U1375B-1R-1, 1-3 cm; Thin Section 227; plane-polarized light). C. Millimeter-size vein filled with carbonates and goethite on wall (upper part of image) (moderately olivine-augitephyric microgabbro) (Sample 330-U1375B-1R-1, 57-59 cm; Thin Section 228; crossed polars).
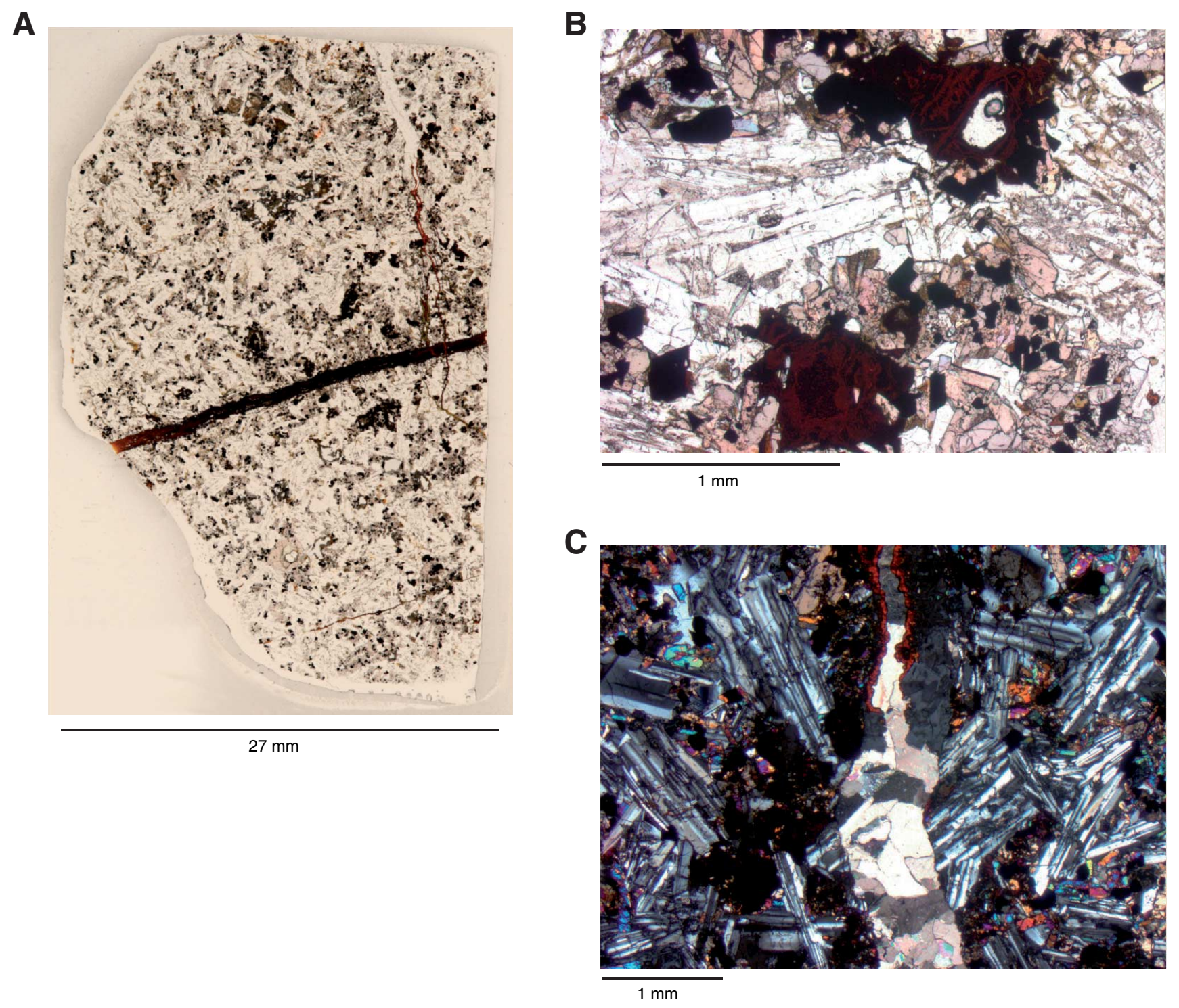
Figure F9. Thin section photomicrographs of veins in moderately olivine-augite-phyric microgabbro (Sample 330-U1375B-1R-1, 57-59 cm; Thin Section 228). Each pair is shown under plane-polarized light (left) and with crossed polars (right). A, B. Veins showing initial filling with green clay, followed by Fe oxyhydroxides and goethite. C, D. Vein showing initial filling by goethite, sometimes with a botryoidal habit, and then with carbonates. E, F. Vein filled with goethite and Fe oxyhydroxides.

A

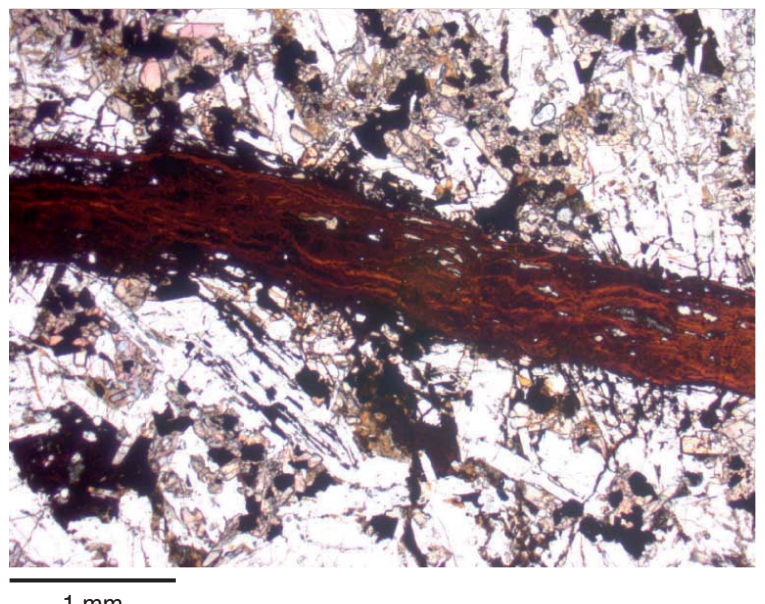

C

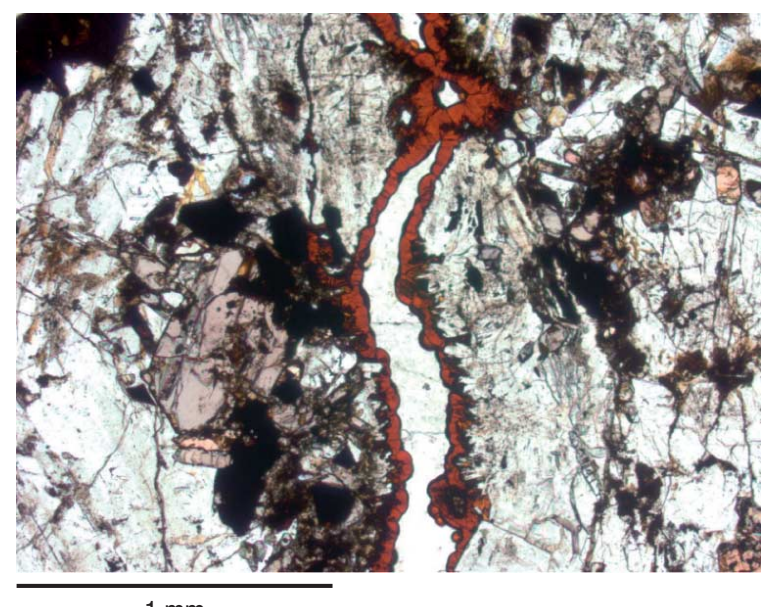

E

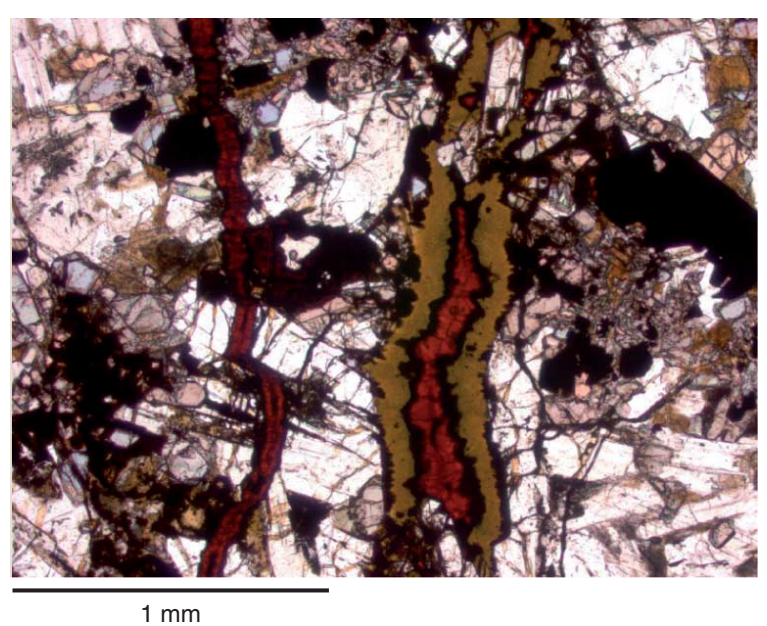

B

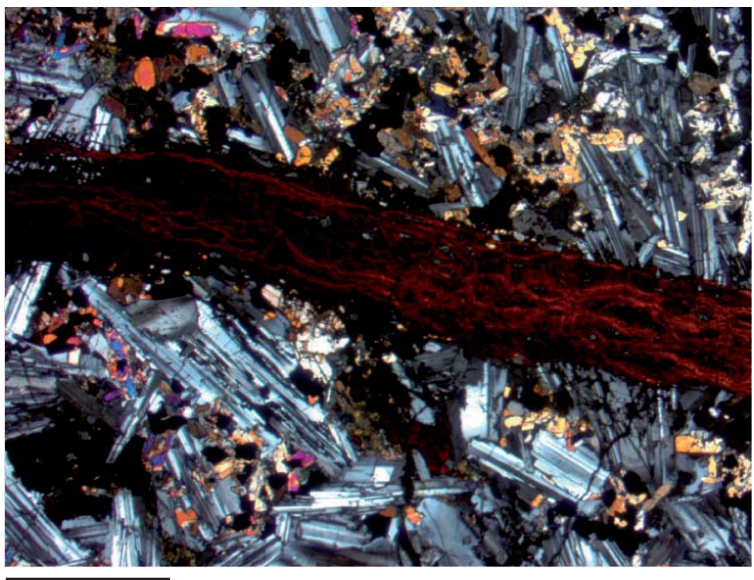

$1 \mathrm{~mm}$
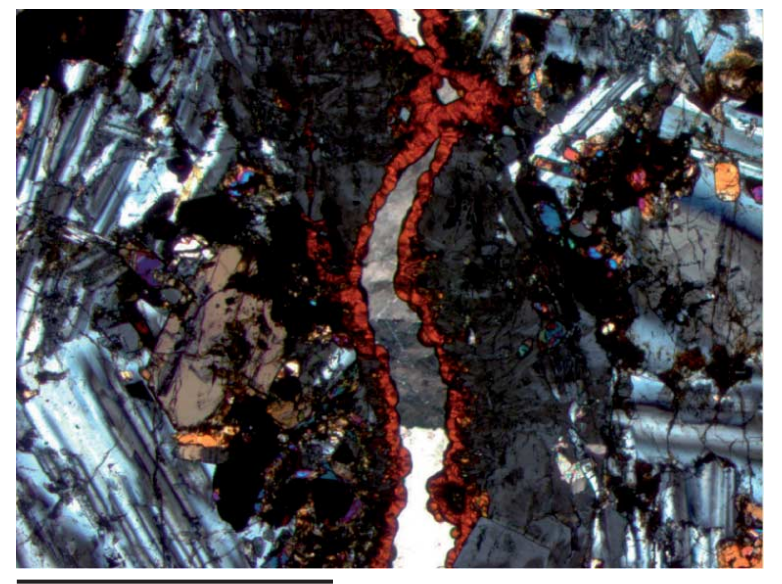

F

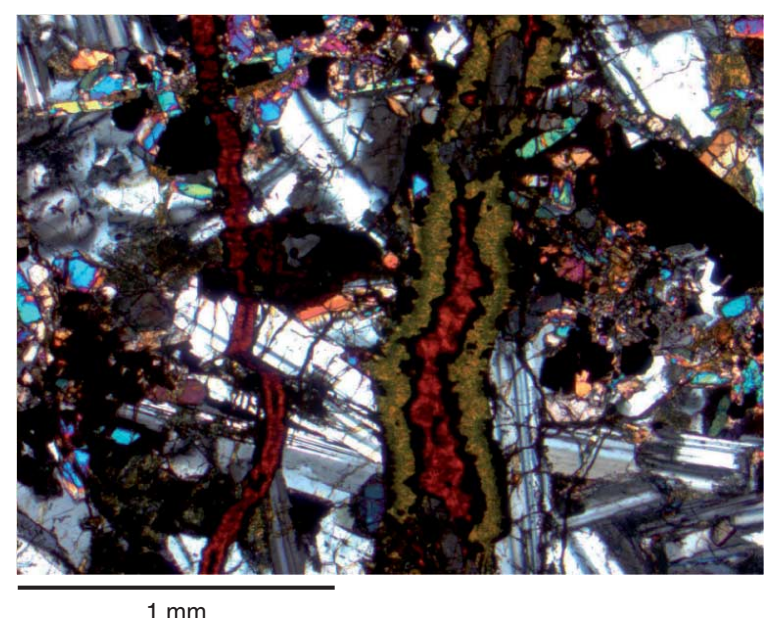


Figure F10. Representative core photographs of geopetals, Hole U1375A. Red arrows indicate geopetals, whereas the blue arrow in $\mathrm{C}$ indicates a small clast separating two halves of the same geopetal. In all cases the lower material is whitish-pink fine-grained sediment, whereas the upper parts of the geopetals are filled by gray, semitransparent calcite. A. Interval 330-U1375A-2R-1A, 32.7-38.2 cm. B. Interval 330-U1375A-2R-1A, 44.7$50.2 \mathrm{~cm}$. C. Interval 330-U1375A-2R-1A, 76.7-83.3 cm.
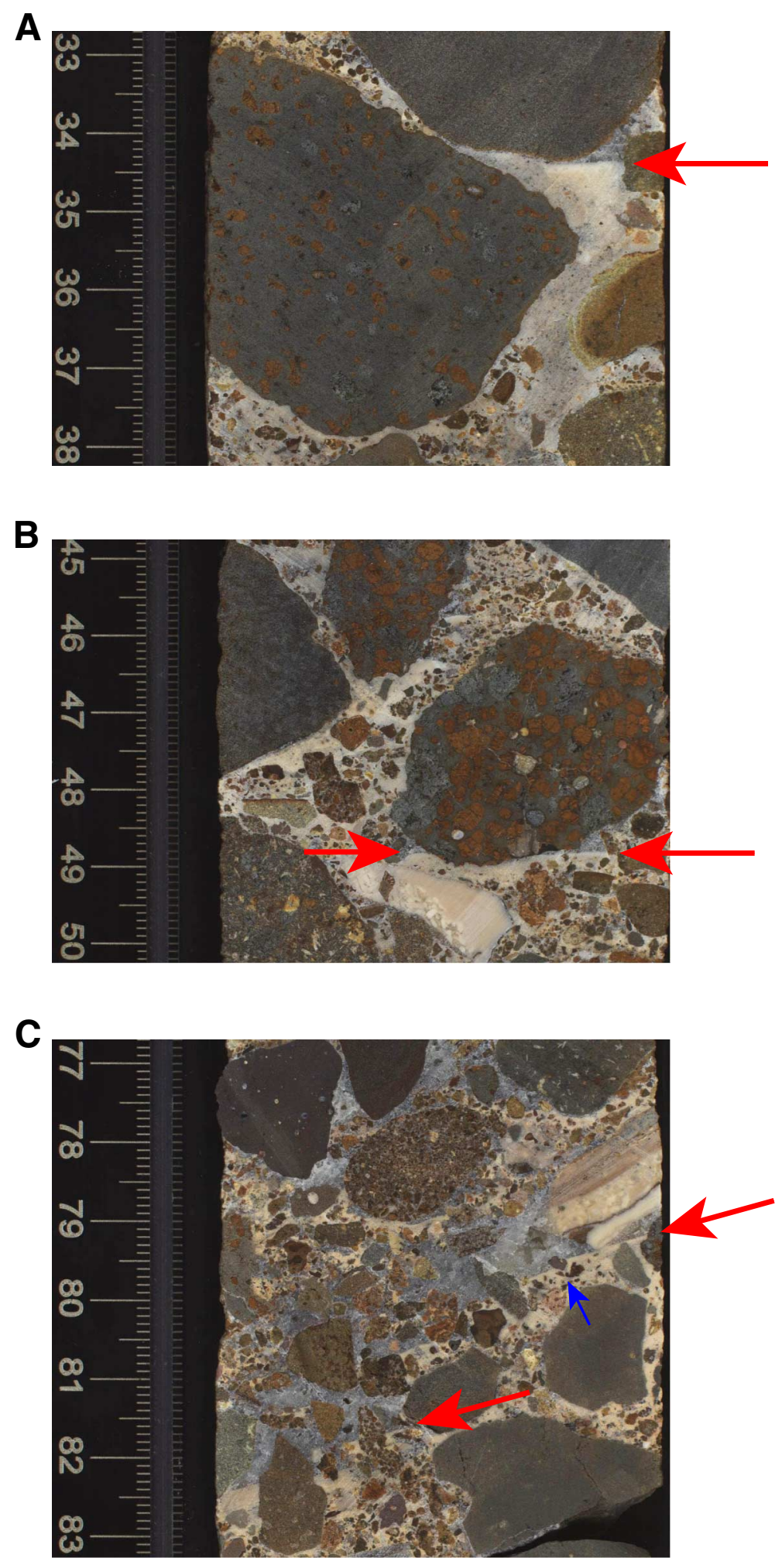
Figure F11. Microgabbro with goethite-calcite-clay veins, Hole U1375B. A. Core photograph showing subvertical veins (red arrows) and subhorizontal veins (blue arrows) (interval 330-U1375B-1R-1A, 41-60.5 cm). B. Rose diagram of vein dip angles relative to the core reference frame.

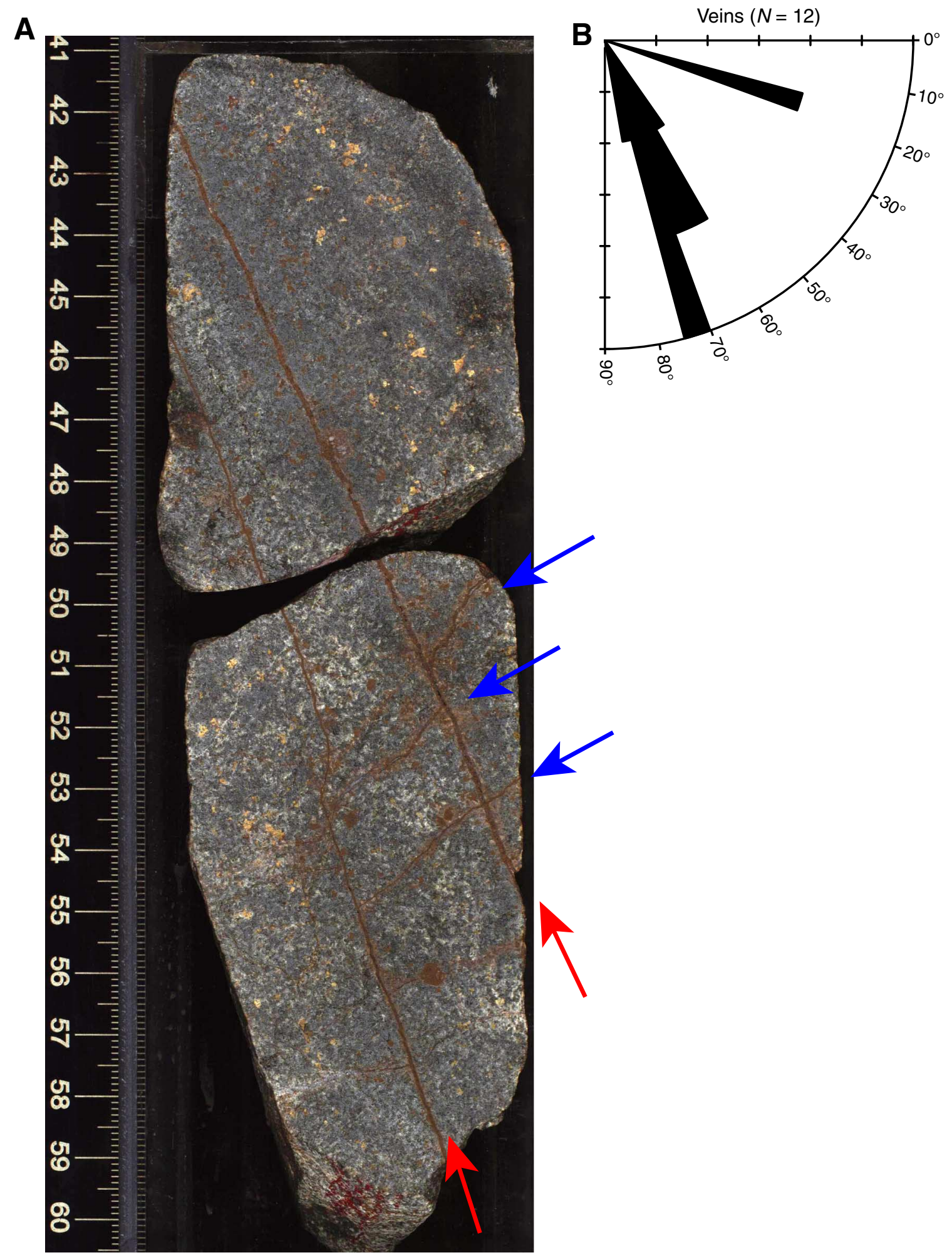


Figure F12. Depth profiles of physical property measurements, (A) Hole U1375A and (B) Hole U1375B. In recovery column, black lines indicate cracks and white intervals indicate gaps between separate pieces, as determined by laser scanner. Stratigraphic columns for each hole are shown for reference. Bulk density: black dots $=$ GRA bulk density, red square $=$ moisture and density method $\mathrm{C}$ measurement on Sample 330-U1375B-1R-1W, 43-45 cm. Higher values of $\mathrm{L}^{*}$ indicate lighter colors, $\mathrm{a}^{*}=$ relative color position between red (positive) and green (negative), $\mathrm{b}^{*}=$ relative color position between yellow (positive) and blue (negative). NGR = natural gamma radiation. (Figure shown on next page.) 
Figure F12 (continued). (Caption shown on previous page.)

A

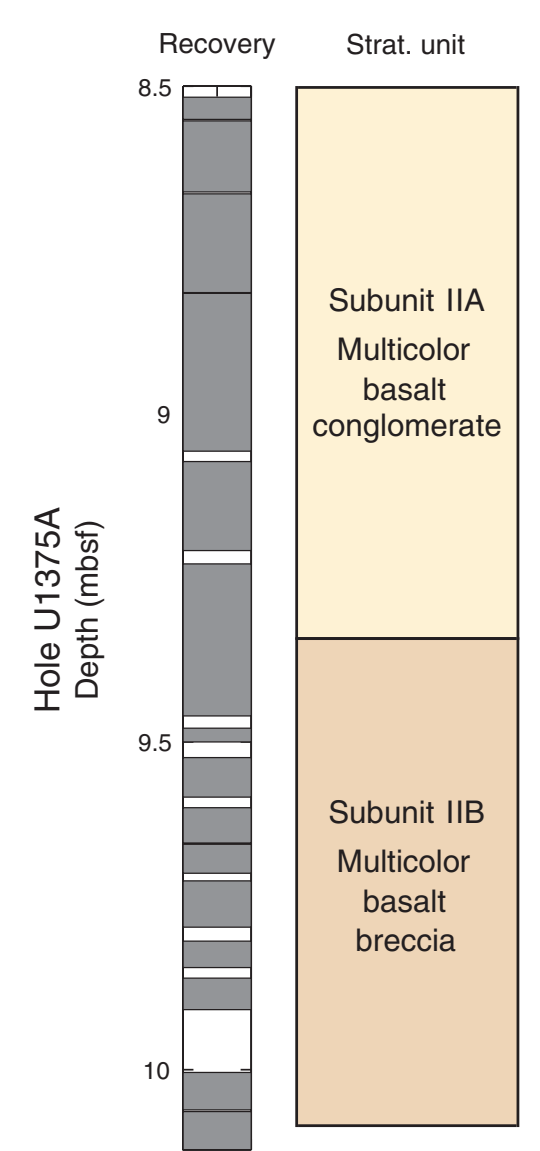

B

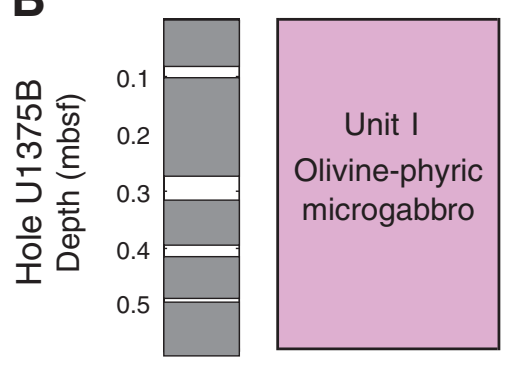

Magnetic susceptibility susceptibility $\left(10^{-5} \mathrm{SI}\right)$
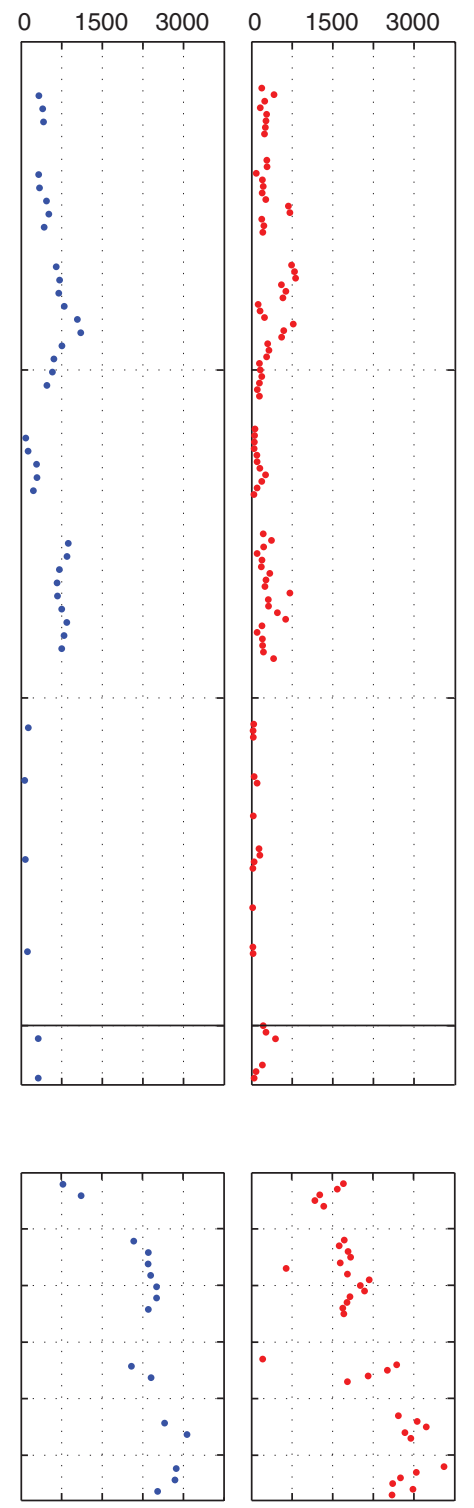

Bulk density

$\left(\mathrm{g} / \mathrm{cm}^{3}\right)$

NGR

$\begin{array}{llllllllllllll}1 & 1.5 & 2 & 2.5 & 3 & 0 & 15 & 30 & 45 & 0 & 25 & 50 & 75 & 100\end{array}$
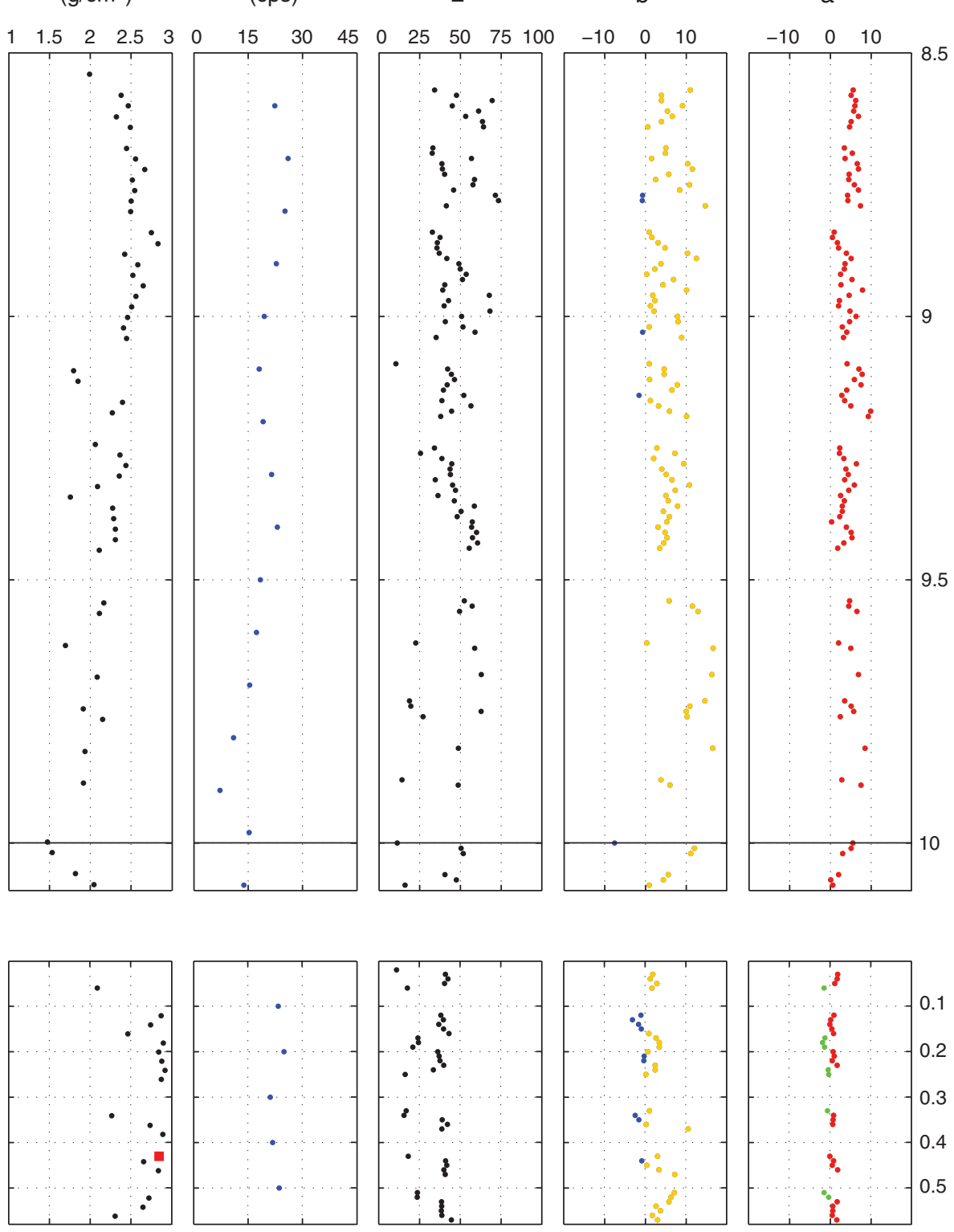
Table T1. Coring summary, Site U1375.

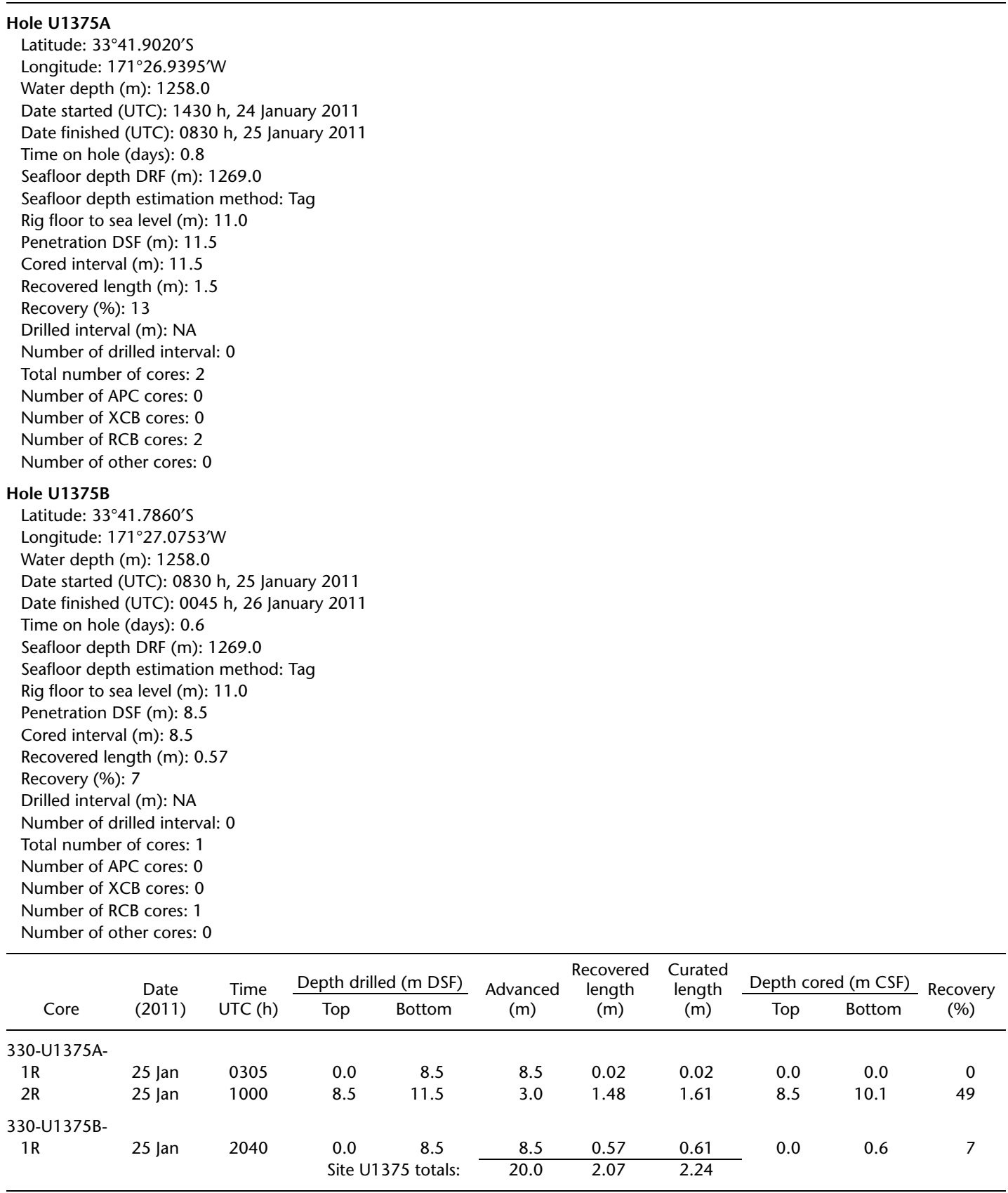

$\mathrm{NA}=$ not applicable. UTC $=$ universal time coordinated. DRF $=$ drilling depth below rig floor, $\mathrm{DSF}=$ drilling depth below seafloor, $\mathrm{CSF}=$ core depth below seafloor. $A P C=$ advanced piston corer (core type $H), X C B=$ extended core barrel (core type $X$ ), $R C B=$ rotary core barrel $($ core type R). 
Table T2. Occurrence of basalt clast types, Site U1375.

\begin{tabular}{|c|c|c|c|c|c|}
\hline \multirow[b]{3}{*}{$\begin{array}{l}\text { Strat. } \\
\text { unit }\end{array}$} & \multicolumn{5}{|c|}{ Basalt clasts } \\
\hline & Type 1 & Type 2 & Type 3 & Type 4 & Type 5 \\
\hline & Aphyric basalt & $\begin{array}{l}\text { Moderately } \\
\text { olivine-pyroxene } \\
\text { phyric basalt }\end{array}$ & $\begin{array}{l}\text { Vesicular aphyric } \\
\text { basalt }\end{array}$ & $\begin{array}{c}\text { Moderately } \\
\text { pyroxene-olivine- } \\
\text { plagioclase phyric } \\
\text { basalt }\end{array}$ & $\begin{array}{l}\text { Highly olivine- } \\
\text { pyroxene phyric } \\
\text { basalt }\end{array}$ \\
\hline IIA & $\mathrm{x}$ & $x$ & $x$ & $\mathrm{x}$ & $\mathrm{x}$ \\
\hline IIB & $\mathrm{x}$ & & & & \\
\hline
\end{tabular}

Details on nature and occurrence of clast types are available in SEDIMENT in "Supplementary material."

Table T3. Distribution of Cenozoic calcareous nannofossils, Hole U1375A.

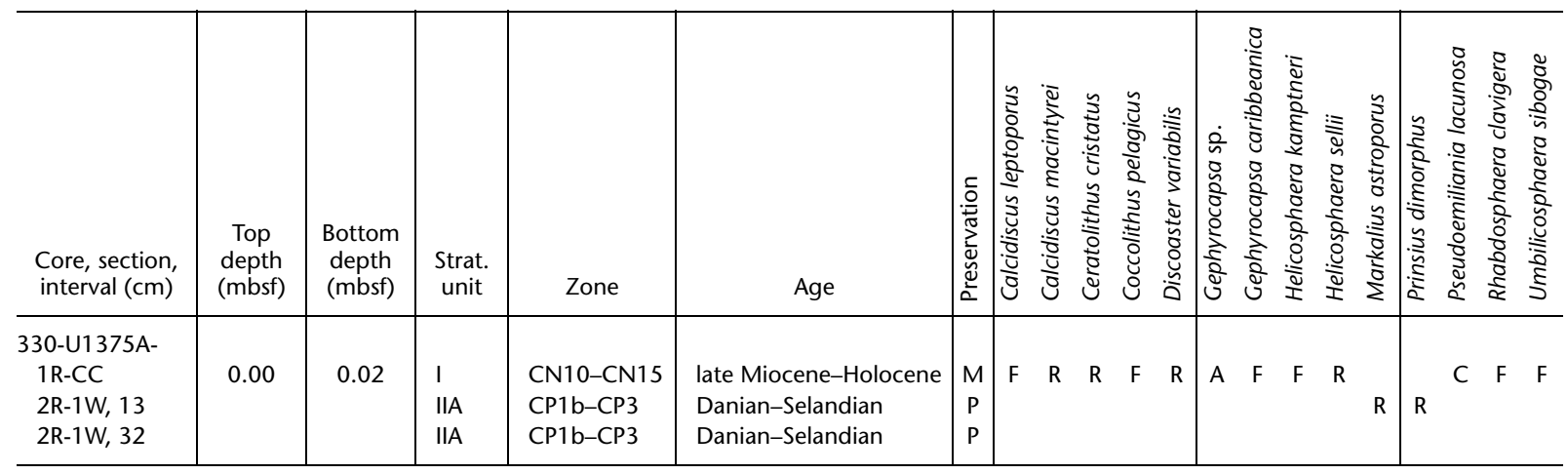

Preservation: $\mathrm{M}=$ medium, $\mathrm{P}=$ poor. Abundance: $\mathrm{A}=$ abundant, $\mathrm{C}=$ common, $\mathrm{F}=\mathrm{few}, \mathrm{R}=$ rare.

Table T4. Distribution of planktonic foraminifers, Hole U1375A.

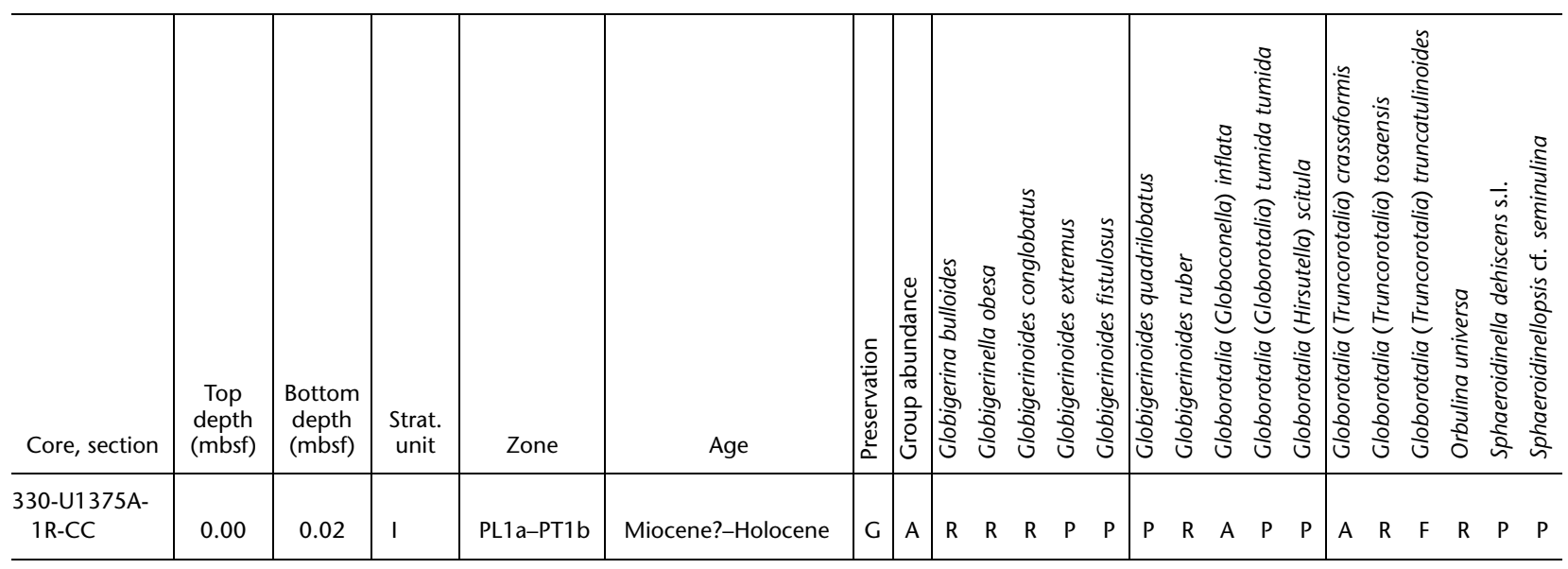

Preservation: $\mathrm{G}=$ good. Abundance: $\mathrm{A}=$ abundant, $\mathrm{F}=$ few $\mathrm{R}=$ rare, $\mathrm{P}=$ present. 
Table T5. Distribution of macro- and microfossils observed in thin section, Hole U1375A.

\begin{tabular}{|c|c|c|c|c|c|c|c|c|c|c|c|c|}
\hline $\begin{array}{l}\text { Core, section, } \\
\text { interval }(\mathrm{cm})\end{array}$ & $\begin{array}{l}\text { Top } \\
\text { depth } \\
\text { (mbsf) }\end{array}$ & $\begin{array}{l}\text { Bottom } \\
\text { depth } \\
\text { (mbsf) }\end{array}$ & $\begin{array}{c}\text { Strat. } \\
\text { unit }\end{array}$ & Zone & Age & 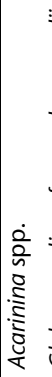 & 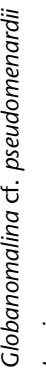 & & & 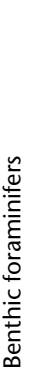 & & 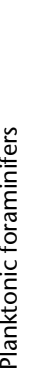 \\
\hline \multicolumn{13}{|l|}{ 330-U1375A- } \\
\hline 2R-1W, 26-29, SLIDE 224 & 8.76 & 8.79 & IIA & P4a-P4c & Selandian-Thanetian & $P$ & $P$ & & & $P$ & $\mathrm{P}$ & $P$ \\
\hline 2R-1W, 26-29, SLIDE 229 & 8.76 & 8.79 & IIA & P4a-P4c & Selandian-Thanetian & $\mathrm{P}$ & & $\mathrm{P}$ & $\mathrm{P}$ & $\mathrm{P}$ & $P$ & $P$ \\
\hline 2R-1W, 26-29, SLIDE 229A & 8.76 & 8.79 & IIA & P4a-P4c & Selandian-Thanetian & $\mathrm{P}$ & $\mathrm{P}$ & & & $\mathrm{P}$ & $P$ & $P$ \\
\hline 2R-1W, 67-70, SLIDE 225 & 9.17 & 9.20 & $\| A$ & ND & Unidentified & $\mathrm{P}$ & & & & $\mathrm{P}$ & $B$ & $P$ \\
\hline 2R-1W, 67-70, SLIDE 230 & 9.17 & 9.20 & $\| A$ & ND & Unidentified & $\mathrm{P}$ & & & & $\mathrm{P}$ & B & $\mathrm{P}$ \\
\hline 2R-1W, 67-70, SLIDE 230A & 9.17 & 9.20 & IIA & ND & Unidentified & $\mathrm{P}$ & & & & $\mathrm{P}$ & B & $P$ \\
\hline
\end{tabular}

$\mathrm{ND}=$ not defined. $\mathrm{P}=$ present (number of individuals was not counted), $\mathrm{B}=$ barren. 
Table T6. Whole-rock major and trace element composition, Hole U1375B.

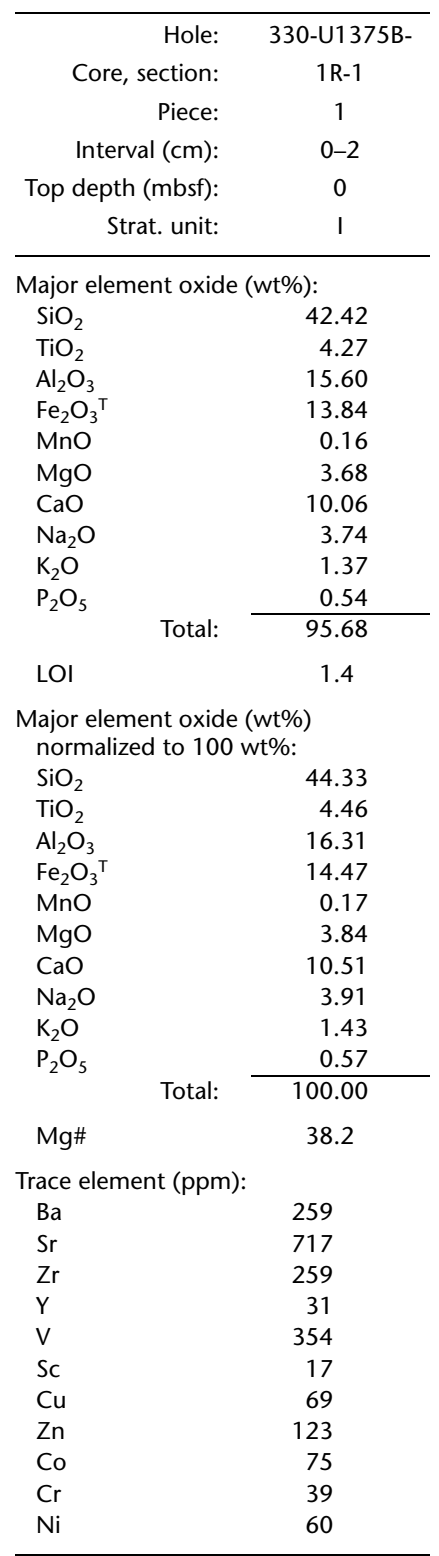

Analysis was conducted on sample powder ignited to $960^{\circ} \mathrm{C}$. $\mathrm{Fe}_{2} \mathrm{O}_{3}{ }^{\top}=$ total iron expressed as $\mathrm{Fe}_{2} \mathrm{O}_{3}$. $\mathrm{LOI}=$ weight loss on ignition. $\mathrm{Mg} \#=100 \times$ $\mathrm{Mg}^{2+} /\left(\mathrm{Mg}^{2+}+\mathrm{Fe}^{2+}\right)$, assuming that $\mathrm{Fe}_{2} \mathrm{O}_{3} / \mathrm{FeO}=0.15$.

Table T7. Moisture and density and compressional wave velocity measurements, Hole U1375B.

\begin{tabular}{|c|c|c|c|c|c|c|c|c|c|c|c|}
\hline \multirow{2}{*}{$\begin{array}{l}\text { Core, section, } \\
\text { interval }(\mathrm{cm})\end{array}$} & \multirow{2}{*}{$\begin{array}{l}\text { Top depth } \\
\text { (mbsf) }\end{array}$} & \multicolumn{3}{|c|}{ Density $\left(\mathrm{g} / \mathrm{cm}^{3}\right)$} & \multirow{2}{*}{ Void ratio } & \multirow{2}{*}{$\begin{array}{l}\text { Water content } \\
(\%)\end{array}$} & \multirow{2}{*}{$\begin{array}{l}\text { Porosity } \\
\text { (\%) }\end{array}$} & \multicolumn{4}{|c|}{ Velocity $(\mathrm{km} / \mathrm{s})$} \\
\hline & & Bulk & Dry & Grain & & & & $x$ & $y$ & $z$ & Average \\
\hline $\begin{array}{r}\text { 330-U1375B- } \\
1 \mathrm{R}-1,43-45\end{array}$ & 0.43 & 2.849 & 2.804 & 2.932 & 0.05 & 1.57 & 4.37 & 6.074 & 5.954 & 6.095 & 6.041 \\
\hline
\end{tabular}

Water content is relative to wet mass. Compressional wave velocity values are accurate to $\pm 20 \mathrm{~m} / \mathrm{s}$. 